ERC Working Papers in Economics 13/10

September/ 2013

\title{
Supplementary Education in Turkey: Recent Developments and Future Prospects
}

\author{
Aysit Tansel \\ Department of Economics, Middle East Technical University, \\ Ankara,TURKEY \\ E-mail: atansel@metu.edu.tr \\ Phone: +(90) 3122102057
}




\title{
Supplementary Education in Turkey: Recent Developments and Future Prospects*
}

\author{
Aysit Tansel \\ Department of Economics \\ Middle East Technical University \\ 06800 Ankara, Turkey \\ and \\ Institute for the Study of Labor (IZA) Bonn, Germany \\ and \\ Economic Research Forum (ERF) Cairo, Egypt \\ e-mail: atansel@metu.edu.tr
}

September 22, 2013

Key Words: Supplementary Education, Demand for Education, Turkey.

JEL Codes: I20, I21, I22

\section{Structured Abstract:}

Purpose: This paper aims to provide the recent developments on the supplementary education system in Turkey. The national examinations for advancing to higher levels of schooling are believed to fuel the demand for Supplementary Education Centers (SEC). Further, we aim to understand the distribution of the SECs and of the secondary schools across the provinces of Turkey in order to evaluate the spacial equity considerations.

Design/Methodology/Approach: The evolution of the SECs and of the secondary schools over time are described and compared. The provincial distribution of the SECs, secondary schools and the high school age population are compared. The characteristics of these distributions are evaluated to inform the about spatial equity issues. The distribution of high school age population that attend secondary schools and the distribution of the secondary school students that attend SECs across the provinces are compared.

Findings: The evidence points out to significant provincial variations in various characteristics of SECs and the secondary schools. The distribution of the SECs is more unequal than that of the secondary schools. The provinces located mostly in the east and south east of the country have lower quality SECs and secondary schools. Further, the SEC participation among the secondary school students and the secondary school participation among the relevant age group are lower in some of the provinces indicating major disadvantages.

Originality/Value: The review of the most recent developments about the SECs, examination and comparison of provincial distributions of the SECs and of the secondary schools are novelties in this paper.

\footnotetext{
* This paper is prepared at the kind request of Janice Aurini, Scott Davies and Julian Dierkes. I am grateful to them for their encouragement and comments. I would also like to thank Hakan Berument and Ali Akarca for providing thoughtful comments on the manuscript and Özgen Öztürk for his help in data preparation. Any errors are my own.
} 


\section{Supplementary Education in Turkey: Recent Developments and Future Prospects}

\section{Table of Contents}

1. Introduction

2. Education System in Turkey

2.1 The National Examination Systems in Turkey

2.2 The High Demand for University Education in Turkey

3. The Supplementary Education Centers in Turkey

3.1 Recent Trends in Supplementary Education Centers

3.2. Disruption of Mainstream Classes

3.3 Determinants of Receiving Supplementary Education

3.4 Effectiveness of Supplementary Education Centers

3.5 Cost of the Supplementary Education Centers

3.6 A Discussion of the TED Survey

4. Provincial Distribution of Supplementary Education Centers and Secondary

Schools

4.1 Intensity of SECs and secondary Schools by Provinces

4.2 Main Characteristics of SECs and Secondary Schools by Provinces

5. Future Prospects

6. Conclusions

References 


\section{List of Acronyms and Abbreviations}

SEC : Supplementary Education Center (Dersane).

YÖK: Higher Education Board of Turkey (Yüksek Öğretim Kurumu)

SBS : Level Determining Examination (Seviye Belirleme Sinavi) for advancing to secondary education.

YGS: Examination for Transition to the Higher Education (Yüksek Öğretime Geçiş Sinav1).

LYS: Placement Examination for Undergraduate Programs (Lisans Yerleştirme Sinavi).

ÖSYM: Student Selection and Placement Center (Öğrenci Seçme ve Yerleştirme Merkezi).

ÖZ-DE-BİR: Association of Supplementary Education Centers (Özel Dersaneler Birliği).

GÜVEN-DER: Association of The Owners of Güven Supplementary Education Centers (Güven Dersane Sahipleri Derneği).

TÖDER: Association of the all Private Educational Establishments (Tüm Özel Öğretim Kurumları Derneği).

TED: Turkish Educational Association (Türk Eğitim Derneği).

ERG: Educational Reform Initiative (Eğitim Reformu Girişimi).

TURKSTAT: Turkish Statistical Institute. 


\section{Introduction}

Private supplementary education is a wide-spread phenomenon all over the world but especially in the East Asian countries. During the recent decades it has spread substantially to the other regions of the world including Western developed countries and more recently to the East European countries. There is a global trend that parents and students around the world resort to supplementary education in response to the competitive pressures in their educational systems.

Parallel to the recent expansion of the supplementary education there is an upsurge of studies on supplementary education recently. Stevenson and Baker (1992) was one of the first to investigate this topic in Japan. They were followed more recently by Bray (1999) who draws attention of the international community on supplementary education with works such as Bray (2003), Bray and Kwok (2003), Silova, Budiene and Bray (2006), Bray (2009, 2010, 2011) and Mori and Baker (2010). Some researchers used the term "hidden market place" and some researchers used the term "shadow education" all to refer to the supplementary education. Burch (2009) used the term "hidden markets" and Bray (1999) coined the word "shadow education" for the supplementary education since it develops parallel to the mainstream education but with different characteristics. Heyneman (2011) summarizes the points in favor of and against supplementary education and states that it may be contrary to the United Nations Declaration of Human Rights. In the context of SECs the issue of equity and social justice arises because wealthy 
families can buy supplementary education in greater intensity and better quality. Safarzynska (2013) examine the gender gap and the production of socio-economic inequalities by supplementary education. Lee, Park and Lee (2009) also suggested that SECs could further the socio-economic inequalities. Bray, Mazawi and Sultana (2013) discuss extensively the issues of SECs and social equity in a number of Mediterranean countries.

Bray (1999) review the research on the effectiveness of supplementary education and finds mixed results. Tansel and Bircan (2005) and Zhang (2013) are some of the limited research in this area. The factors that contribute to the growth of supplementary education all over the world are different and its extent varies widely among the countries. Ireson (2004) examine this topic in Ireland and Bray and Kwok (2003) examine the system in Hong Kong. Bray (2011) considers the supplementary education in the European Union which is a region studied less often. Bray and Suso (2008) study the patterns in Africa and Bray and Lykins (2012) examine the same in Asia. Silova (2009) consider the developments in supplementary education in Central Asia, Silova (2010) in Eastern Europe and Central Asia and Silova, Budiene and Bray (2006) in Eastern European countries.

Supplementary education is especially wide-spread in the countries where there are national examinations in selecting students in their transitions to upper levels of schools. There are national, central examinations for transitions to higher levels of schooling in many countries such as South Korea, Hong Kong, Greece, Japan and Taiwan. The system of SECs is most prevalent in these countries. The system of supplementary education in Turkey is believed to have developed as a 
result of such national, central examinations. In 2012 there were close to four thousand registered Supplementary Education Centers (SEC) with 1.3 million students and about fifty-two thousand teachers in Turkey. The interest by the researchers and the academicians on this topic in Turkey is rather recent. Tansel (2013) investigate the equity issues in relation to supplementary education. Tansel and Bircan (2005; 2006 and 2007) study the effectiveness, the determinants and other aspects of the supplementary education. Berberoglu and Tansel (2013) also investigate the effectiveness considerations of the supplementary education. These studies devoted to various aspects of supplementary education in Turkey use mostly survey data and quantitative methods. Altınyelken (2013), Nartgün, et al. (2012), Baştürk and Doğan (2010), Gök (2006; 2010), Akgün (2005), Güvercin (2005), Okur and Dikici (2004), Morgil, Y1lmaz and Geban (2001) and Morgil, Y1lmaz, Seçken and Erökten.(2000) are the other studies that indicate the extent of the growing interest on the topic of supplementary education by the Turkish academicians. There are also several reports prepared by governmental and nongovernmental organizations on the university entrance examination system and the SECs in Turkey. For example, the Turkish Educational Association (TED) prepared a report based on an extensive survey of students, parents, teachers and school administrators (TED, 2005). The results of this report are covered in Section 3.6 of this paper. Higher Education Board (YÖK) which is an independent organization published a report on the universities in Turkey (YÖK, 2007). The Trade Union of Educators (Eğitim-Sen) publishes their views on the public and the private schools as well as SECs in Turkey (Eğitim-Sen, 2013). 
This study will provide information on various aspects of private supplementary education in Turkey. In particular the provincial distribution of the SECs and of secondary schools will be addressed. Organization of the paper is as follows. Section 2 will review the educational system in Turkey and the two national examinations considered responsible for the development of the SEC system. The transition from middle school to high schools generates a demand for the services of SECs. Similarly, the transition from high schools to universities creates a second wave of demand for the services of SECs. The reasons for the high demand for university education in Turkey and therefore the derived demand for services of the SECs are discussed in Section 2.2. Section 3 reviews the recent trends and the developments in the in the SECs and the secondary schools. The disruption of mainstream classes close to the national examination times, effectiveness of SECs, determinants of attending SECs and the cost of the SECs are also addressed in this section. Provincial distribution of supplementary education centers, general high schools and the high school age population are considered in Section 4 along with discussions of the various characteristics of the provincial distributions of the SECs and of the secondary schools including their provincial intensity and quality by various measures. This section is expected to shed light on the spatial equity issues in the distribution of SECs and secondary schools among the provinces of Turkey. Section 5 is a discourse on future prospects of the SECs. Finally, concluding remarks are given in Section 6.

\section{Education System in Turkey}

Education system in Turkey consists of basic education, secondary education and tertiary education. Primary schooling of five years was the only compulsory 
level of schooling until educational reform of 1997. In 1997 primary schooling and the three years of middle schooling was combined into one unit and called basic education. The basic education which took 8 years became compulsory in 1997. Basic education is followed by three years and since 2005-2006 four years of secondary education. The secondary education could take place at the general high schools or vocational high schools. In the 2012-2013 academic year an educational system referred to as $4+4+4$ was instituted and 12 years of education covering high school became compulsory. One of the main novelties of this system is introduction of streamlining after grade four. The second four year stage is called middle school. Under this system children start schooling at 66 months of age. There was not a public consensus about this system. This system is criticized extensively by many educators. Both the reduction of school starting age and the early streamlining were the main objects of criticism by the public and the educators. Many parents resorted to taking medical reports for their children in order to delay for another year their children's start of school at 66 months. Reports by the Educational Reform Initiative such as ERG (2012) and reports by the deans of various schools of education at the universities contributed to the criticisms of the $4+4+4$ system.

The tertiary education in Turkey takes place at the universities. Universities take two-four years (medical schools six years) depending on the program of study. Four years lead to a Bachelor's degree. The two-year programs lead to the so called Associate Degree. There are also masters and Ph.D. degree programs. In view of the excess demand for tertiary level education, the number of both the public and the private universities has increased substantially during the past two decades. In 1992, 25 additional public universities were established. In 2006, 15 new 
universities are established. A recent law of April 2007 stipulated the establishment of 17 additional new universities. Currently there are 166 universities all over the country while previously there were only a handful of universities only in the major cities. Of the 166 universities 62 are private universities (YÖK, 2013). Private universities in Turkey are non-profit organizations owned by foundations. Operation of for-profit universities is banned by the constitution. There is also an Open University which is a distance university. The distance university is one of the largest distance universities in the world in terms of its number of students.

Although state is the major provider, there are a number of private providers at all of the three levels of education. For example, in the academic year of 20122013, of the total of 29169 primary schools, 3 percent were private primary schools. Of the total of 16987 middle schools 5 percent were private middle schools. Of the total of 4214 high schools 21 percent were private high schools (Ministry of National Education, 2013). Therefore, there were more private schools at the high school level than at the other school levels.

\subsection{The National Examination Systems in Turkey}

There are two national examinations in Turkey which determine who will advance to the upper levels of schooling. The first examination is called Level Determining Examination, SBS in short. This examination is taken by the students of middle school in their senior year and determines who will go to the elite "special" high schools which are much in demand. Others can attend general high schools or vocational high schools for which there is no entrance examination. In 
2013, 1.1 million students took the SBS examination to compete for entry into elite "special" high schools. .

The elite "special" high schools are believed to provide better quality education and their graduates are believed to have higher chance of success at the university entrance examination. These schools include Anatolian high schools, Science high schools, Social Sciences high schools and private high schools. Recently, the number of Anatolian high schools is increased substantially (by converting regular high schools to Anatolian high schools) in response to the high demand for such schools. Anatolian high schools are public schools and give full day instruction unlike regular high schools and have class sizes less than 30 students. Most of the Anatolian high schools teach in English but some teach in French or German. As of 2012-2013 academic year there were 1627 Anatolian high schools, 144 science high schools, 907 private high schools and 1111 regular high schools. These constituted the 39 percent, 3.4 percent, 22 percent and 26 percent of the total high schools, respectively (Ministry of National Education, 2013). In the same year there are a total of 4213 various types of general high schools $79 \%$ of which were public and 22\% which were private high schools. Further, in 2012-2013 there are a total of 10418 secondary schools $40 \%$ of which were various types of general high schools and $60 \%$ of which were vocational and technical high schools (Ministry of National Education, 2013).

There have been several changes in this examination system during the past decade. The SBS examination system was first called LGS, then OKS afterwards SBS and they are all administered by the Ministry of National Education. In an 
attempt to reduce the role of supplementary education centers, Ministry of National Education announced in March 2007 that SBS will be held every year during the last three years of the basic school $\left(6^{\text {th }}, 7^{\text {th }}\right.$, and $8^{\text {th }}$ grade) (Ministry of National Education, 2007). For a discussion of this system see Tansel and Bircan (2007). Currently, since 2011-2012 academic year, SBS is being administered only in the senior year of middle school ( $8^{\text {th }}$ grade). In 2013, 1.1 million students took the SBS. On July 3, 2013, the Minister of National Education announced that SBS will be eliminated and SECs will be closed down. This created havoc in the public. For further discussion of this issue see Section 5 of this chapter.

The second national examination determines the advancement to Universities. It is administered by an independent organization called ÖSYM (Student Selection and Placement Center). Unlike SBS which is relevant only for admission to "special" high schools, University entrance examination must be taken by all students who want to be placed at a public or private university program. Not all of the 166 universities scattered around the country are considered of the same quality in terms of the job market prospects of their graduates and the salaries they command. In some of the public universities some programs of study are conducted in English Most of private universities provide instruction in English. Competition for placement at a "prestigious" public or private university- most of which use English as the medium of instruction- is fierce.

The high demand for learning English is the reason as to why some high schools and some universities use English as the medium of instruction. Indeed, there are high monetary returns to knowledge of English language in the Turkish 
labor market (Di Paolo and Tansel, 2013). However the SECs do not use English or any other foreign language in their instruction system possibly because SBS and the university entrance examinations (YGS and LYS) are all conducted in Turkish except the foreign language examinations of LYS.

In 2012, 1895478 applicants took the university entrance examination. Of those applicants 42 percent were senior high school students and 30 percent were high school graduates 9 percent were registered at a university program and 3 percent were already graduates of a university. Overall only 19 percent of the total applicants was placed at a four-year university program and 15 percent was placed at a two-year university program. Further, 12 percent of the total applicants was placed at the Open University (Ministry of National Education, 2013, Student Selection and Placement Center, 2013). As remarked earlier the open university in Turkey is one of the largest in the world with close to 800 thousand students in 2012-2013. This implies that about 15 percent of the total university students are attending the open university of Turkey.

As indicated above, 42 percent of the university entrance examination applicants were high school seniors in 2012 which implies that most of the remaining 58 percent were repeat-takers. The rather high percent of repeat-takers imply that most high school graduates spend a year or more in preparation for the university entrance examination often by attending a SEC.

The wide differences in the quality of secondary schools can be observed by the percentage of the applicants from these schools that are placed in a four-year or 
two-year university program. Following success rates which give the percentage of the applicants that got placed in a university program give an idea about the quality of the various secondary schools. These statistics pertain to the university entrance examinations in 2011-2012. Among the applicants from various high schools the success rate was 24 percent at a four-year university program and 10 percent at a two-year university program. Conversely among the applicants from a vocational and technical high schools the success rate was 7 percent at a four-year university program and 26 percent at a two-year university program. These statistics give an idea about the differences between high schools and vocational and technical high schools in terms of their orientation and functions.

Besides these general rates for the high schools and vocational and technical high schools, we can also consider the success rates for the various high schools. Among the applicants from Anatolian high schools the success rate at the four-year university programs was 54 percent (two percent at the two-year university programs). The success rate among the applicants from the foreign language private high schools was 55 percent ( three percent at the two-year programs). The success rate among the applicants from science high schools at a four-year program was 60 percent (less than half a percent at the two-year programs) and that of the private science high schools was 65 percent (about half a percent at the two-year programs). The success rate of the applicants among the social science high schools was 75 percent at the four-year programs (none at the two-year programs). Finally, the success rate of the applicants from the regular public high schools was 20 percent at a four-year university program (11 percent at a two-year program). The success rate of the religious vocation high schools (excluding those from the Anatolian religious 
vocation high school which have higher rates) was 13 percent at a four-year university program (six percent at a two-year university program) (Ministry of National Education, 2013). These statistics indicate especially low success rates among the applicants from regular public high schools and higher rates among the science high schools and Anatolian high schools. These point to the substantial quality differences among the various high schools. Berberoğlu and Kalender (2005) find that differences between high school types in terms of the success of their students in the university entrance examinations and some international tests are larger than the regional differences. Dinçer and Uysal (2010) emphasize the importance of family background in student attainments.

It is also noteworthy that most of the students who attend the science high schools and Anatolian high schools which are good quality public high schools, free of charge, are from wealthy families. According to the World Bank (2011) twothirds of the science high school students and one half of the Anatolian high school students come from the richest 20 percent of the household. This point has serious equity and social justice implications.

\subsection{The High Demand for University Education in Turkey}

There is a very high demand for university education in Turkey which may be due to several factors. The foremost factor is the very high private monetary returns to university education in Turkey. Tansel (1994, 2001, 2005 and 2010) show that over the years the highest monetary returns are attained at the university level of education which are higher than to other levels of education by a large margin. 
Therefore, the possibility of high earnings is a main reason behind the high demand for university education. The second main reason is the increased job finding ability with a university degree. Tansel and Taşçı (2010) note the higher probability of finding a job out of unemployment for the university graduates compared to the unemployed at other levels of education. Further, university graduate men can serve his military service as an officer rather than as a private soldier. Finally, an university graduate enjoys a prestigious position in Turkish society as it is in other countries

The above discussed advantages render university education very desirable for the young and their parents. As remarked in the previous section, parents first spend on supplementary education in order to place their children into elite "special" high schools which are believed to increase their chances of placement at a university program. Next, parents spend one more time on supplementary education in order to place their children at a "prestigious" university program. The graduates of such universities command higher earnings in the Turkish labor market and prestigious positions in the society. For this reason parents invest into supplementary education of their children with great sacrifices. At this point a related issue is that parents who spend large sums on sending their children to private high schools and SECs, pay no tuition once their children are placed at a "prestigious" public university.

\section{The Supplementary Education Centers in Turkey}


Supplementary education can take in three different forms in Turkey as it is in other countries. One kind is one-to-one individualized teaching by the tutor. The second form is teaching by mainstream teachers for a nominal fee outside of the formal class hours at the premises of the mainstream schools. The third type is provided by the supplementary education centers (SEC) which are school-like organizations operating for profit. SECs are called "dersane" in Turkish. See Section 3.2 for the licensing requirement of the SECs. Tansel and Bircan (2006 and 2007) present a detailed discussion of the forms of Supplementary education in Turkey. SECs offer examination oriented courses for entry to the elite "special" high schools (SBS examination) and for entry to the universities (YGS and LYS examinations). They also teach techniques on how to prepare for these examinations as well as provide counseling and guidance services on the choice of universities, on the choice of study fields at the universities and future career selection as well as personal development and dealing with examination stress.

During the 2011-2012 academic year there was a total of 1.3 million SEC students at approximately four thousand SECs with about 52 thousand teachers as can be observed in Table 1. Table 3 shows that over the years more boys attended SECs than girls. The gender gap somewhat closed during the recent years. In any case the gender gap -however slight- may be related to differences in the male and female students' preference for various university programs. It is possible that female students disproportionately choose social sciences and language studies rather than technical fields. If this is true then they will need less supplementary education. 
The organization of SECs go back to early 1960's They were legally recognized in 1965 and a law passed governing their operation. Throughout the 1970s there were public discussions about the equity implications of the university entrance examinations and the SECs which led to their banning 1980. But, the ban was lifted a year later before it is implemented. Currently SECs operate with a license from the Ministry of National Education and under its surveillance. They are legally established, tax paying businesses. The licensing is a registration process as well as an accreditation process. Tansel and Bircan (2006 and 2007) provide detailed discussion of the history and organization of the SECs.

\section{ÖZ-DE-BİR, GÜVEN-DER and TÖDER are the associations of SECs} with membership on a voluntary basis. ÖZ-DE-BİR is the largest and the oldest of these associations. Further information about the associations of SECs are provided in ÖZ-DE-BİR (2013), GÜVEN-DER (2013) TÖDER (2013) and Tansel and Bircan (2006 and 2007) ÖZ-DE-BİR officials claimed that there are at least an additional two thousand SECs operating unofficially without a license as part of the underground economy of Turkey. They not only avoid paying taxes but also avoid inspection by the Ministry of National Education and cause unfair competition for the legal SECs. The three associations administer jointly a national a mock university entrance examination. Morgil, Y1lmaz, Seçken and Erökten (2000) found close correlation between the results of the mock and the real entrance examinations. SECs are required to register five percent of their students from low income families free of charge. ÖZ-DE-BİR officials state that in practice this often exceeds the officially required five percent for their members. Most SECs give an initial placement test for their applicants. Students who do best on these tests are registered 
free of charge or at a reduced rate for advertisement purposes. Further details of this process are provided in Tansel and Bircan (2007).

\subsection{Recent Trends in Supplementary Education Centers}

Table 1 gives the recent trend in the numbers, students and teachers of SEC's and related statistics. During the 1975-76 academic year there were only 157 SEC's throughout the country which increased to about four thousand in 2011-2012 academic year. The number of SEC students increased from about 46 thousand to 1.3 million in 2011-2012. The number of teachers employed at the SEC's reached 52 thousand in 2011-12. Thus, the SEC's are a significant outlet in employing people with "teacher" training. The number of teachers employed per SEC was about 13 teachers in 2011-2012. The average number of students per SEC reached 332 in 2012-2013. The SEC's in Turkey are thus of medium size. They are not very large enterprises by the standards of the SECs in Hong-Kong. (Bray and Kwok, 2003). The number of students per teacher in SEC's ranged between 22-33. Table 1 also shows that the number of SECs reached a peak in 2007-2008 with 4.3 thousand. It has declined since after that date while the number of students and teachers are increasing. However, one must consider that the number of students per SEC and the number of teachers per SEC both increased while the number of students per teacher did not change substantially. This implies that while the number of SECs declined and the number of students increased the quality of the SECs did not get affected.

Take in Table 1

Table 2 gives the recent developments in the various characteristics of the secondary schools in Turkey. The secondary schools include both the high schools 
and the vocational and technical high schools. According to this table, the numbers of secondary schools, the number of their graduates, students and teachers have all increased substantially over time. The number of students per secondary school has increased over time and in 2012-2013 it is about 500 students per establishment. The number of teachers per secondary school varied over time and it was 25 teachers per establishment in 2012-2013. The number of students per teacher indicating the quality of the secondary schools has varied over time but was about 20 students per teacher in both of the 2011-2012 and 2012-2013 academic years.

Take in Table 2

The rules about allowing vocational and technical high school students to sit in the university entrance examinations have changed several times during the past decade. A discussion of this is available in Tansel and Bircan (2007). Currently they are allowed to sit in the university entrance examinations and there was an influx of them to the SECs when they were fist allowed to take the university entrance examination (Tansel, 2013).

In conclusion, judging by the number of students per establishment the SECs are smaller establishments than the secondary schools: 332 students in SECs versus 492 students in secondary schools in 2011-2012. In contrast, the number of students per teacher at the SECs is higher than at the secondary schools: 25 students versus 20 students, respectively in 2011-2012 (see Tables 1 and 2).

In spite of the fact that returns to women's education is higher or at least as large as those to men in Turkey (Tansel, 1994, 2001, 2005 and 2010), parents invest more into educating their sons than into their daughters (Tansel, 2002a) especially 
when household resources are limited Tansel (2002a). Same may be true in case of supplementary education also. Assaad and El-Badawy (2004) in Egypt consider the gender issues in supplementary education. Tansel and Bircan (2005) found that the probability of receiving supplementary education is lower among females in Turkey. Table 3 shows the numbers and the proportions of the male and female students at the SECs versus among the secondary school graduates during the period of 20002001 to 2011-2012. The proportion of the male students is higher than that of the female students both among the SECs and the secondary school graduates in the early 2000s. That is the gender gap was somewhat large at both the SECs and among the secondary school graduates. About ten years later the gender gap has almost disappeared in both the SECs and among the secondary school graduates and even reversed slightly among the secondary school graduates.

Take in Table 3

\subsection{Disruption of Mainstream Classes}

It is a well-known observation that attending SECs and the process of preparation for the two national examinations disrupt the formal schooling attendance during the second semester of the senior students who are preparing for the SBS and the YGS (takes place in April) and LYS (takes place in the second half of June). During this period the students concentrate on attending the SECs and on their own preparations at home rather than attending mainstream classes. The Ministry of National Education allows the senior students in their last semester to be absent from mainstream classes for 45 days. The students who need more time than this resort to false medical reports of sickness in order to be absent from their mainstream classes. Acquiring such a report is widely accepted and an expensive process. Recently, the 
president of the Independent Educators Union (2007) gave a statement that false medical reports of sickness undermine the "psychological and ethical development" of the children teaching them how to cheat the establishment. This is an aspect that has been totally ignored in the public discussions. Further discussions of this issue in relation to SBS and the university entrance examinations are provided in Tansel and Bircan (2007).

\subsection{Determinants of Receiving Supplementary education}

Tansel and Bircan (2006) examined the determinants of the household expenditures on supplementary education in Turkey. Their findings emphasize the importance of household income and parental education levels as the most important determinants. They also found a larger effect of the mother's education than that of the father's education. Tansel (2002a) also found that the parental education level is the most important factor determining the educational attainment of children in Turkey after household income. Tansel and Bircan (2005) examined the factors that contributed to the probability of receiving supplementary education. The high school graduation ranking of the student was found to be the most important factor pointing out to the importance of motivation and the ability of the students. Zhang (2013) find that students with high achievement benefit more from supplementary education. In conclusion, the students with high academic ability, high household income and highly educated parents receive more supplementary education. Further discussion of this topic can be found in Tansel and Bircan (2007). 


\subsection{Effectiveness of Supplementary Education Centers}

There are a few studies examining the effect of supplementary education on academic achievement. Dang and Rogers (2008) consider this issue among others. Bray (1999 and 2006) review the research on the effectiveness of the SECs and find mixed results. Some studies found positive influence of supplementary education on academic achievement performance while some studies found no correlation between supplementary education and academic achievement. Tansel and Bircan (2005) find that attending SECs during the senior year in high school increased significantly the probability of getting placed in a university program. Further, attending SECs increased the test scores significantly in most of the subjects in the university entrance examination among the applicants to the university entrance examination in 2002. Morgil, Y1lmaz, Seçkem and Erökten (2000), Okur and Dikici (2004) also reported that those who receive supplementary education exhibit better examination performance. Ekici (2005) find that students who attend SECs have a positive attitude towards university entrance examinations as compared to those who do not attend the SECs. Further discussions can be found in Tansel and Bircan (2005 and 2007).

\subsection{Cost of the Supplementary Education Centers}

Köprülü (2012) who is the president of ÖZ-DE-BİR reported an estimate of 1.5 to 2 billion USD as gross income of SECs. This amounts to 0.19 to 2.6 percent of Turkey's Gross Dometic Product (GDP) in 2012. In contrast, the national government expenditures on education were 3.0 percent of the GNP of Turkey in 2006. The per capita GDP of Turkey in 2011 was 10444 USD. Kim (2008) notes that in South Korea parents invest 20 billion USD in supplementary education. 
According to the information provided by Köprülü (2012) the average annual fee of the SECs' range between 300- 2250 USD for the preparation to SBS depending on location. It ranges between 1 100-3 300 USD for the students in the first three years of the high schools and it ranges between 1700-5 600 USD during the senior year of the high school again depending on location. In contrast, the annual minimum wage for adults was about 5000 USD in 2012 (Tansel, 2013). There are also the so called "boutique" SECs in cities like Istanbul, which cater to wealthy. Their class sizes are a maximum of 6-8 students and their annual average cost is within the range of 8 000- 12000 USD.

\subsection{A Discussion of the TED Survey}

Appendix Table provides the selective results of a survey by TED among high school seniors, high school graduates and university students. An extended version of this table which includes the responses of the parents, teachers and the school administrators is given in Tansel and Bircan (2007) together with a detailed discussion of the results of this survey. Here, only a brief summary will be provided. According to the results in the Appendix Table, more than half of the high school seniors feel that there is nothing in their life now more important than the university entrance examination. Further, at the time of the survey between 70-83 percent of the respondents were attending SECs. More than half of the respondents believed that school education is not adequate for success in university entrance examination. Close to half of the respondents stated that their teachers and school administrators absolutely want them to attend the SECs. 
When asked to compare the quality of education at the SECs and at the mainstream schools, 34-65 percent of the respondents indicate that the quality of education is better at the SECs than at the mainstream schools. Further, among each of these groups a substantial percent stated that SECs teach only examination techniques.

Close to 70 percent of the respondents agree that quality of high school is an important determinant of success at university entrance examination. This makes it clear as to why students strive to enter a better high school at SBS and most parents consider the past performance of the high schools at the university entrance examination while making choice of high schools for their children. The SECs and the secondary schools both provide counseling and guidance services in selecting universities, study fields and future careers as well as in the issues of personal development, dealing with examination stress and developing efficient work habits. A high proportion of the respondents believe that these services are better at the SECs or are similar in both places. Some educators claimed that SECs are substituting for the high schools in both teaching and as a place where students socialize. When asked whether the SECs or the schools they like better, same proportion of the students liked SECs or the schools however, majority of them like both places.

The Appendix Table also provides the hours of education per week received at the SECs by various groups. This information indicates that 51 percent of the high school seniors attend SECs for 10-20 hours per week while 84 percent of the high school graduates attend SECs for 15-20 or more hours per week. The high school 
graduates attend SECs for more hours per week than the other groups. This group is possibly repeat-takers of the university examination with full time preparations.

Over half of the respondents said that they will receive a false medical report of sickness for their non-attendance to the mainstream school while a quarter of the respondents said that they will use the legally allowed non-attendance days while about 19-34 percent of the respondents stated that they will continue mainstream schools as usual. Is it possible to succeed at the university entrance examination without attending SECs? A larger percentage of the respondents believe that it is difficult or not possible. Further, over half of the respondents believe that SECs will contribute a lot to their success at the university entrance examinations. Finally, over half of the respondents were satisfied with the SECs they are attending.

\section{Provincial Distribution of Supplementary Education Centers and}

\section{Secondary Schools}

\subsection{Intensity of SECs and Secondary Schools by Provinces}

This section considers the provincial distribution of the SECs and secondary schools in Turkey. In this section we consider the total of secondary schools which include general high schools and vocational and technical high schools. For the purposes of comparison we do not use just high schools because we believe that the total of the high schools give a better indication of the secondary school educational opportunities for the secondary school age children. Further, currently the vocational and technical school students are allowed to sit in the university entrance examinations just like the general high school students giving them the same 
opportunity for further education albeit with a lower chance to succeed in that examination (Tansel, 2002b). Table 4 provides the numbers of SECs and secondary schools across the 81 provinces of Turkey during the academic year 2011-2012. The provinces are listed from the highest number of SECs to the lowest. Istanbul has the highest number of SECs with 710 and also the highest number of secondary school with 1179. Ankara has the second highest number of SECs with 384 and the secondary schools with 590. At the other extreme Ardahan and Bayburt each has only two SECs and 25 and 17 secondary schools respectively. The last column in this table gives the number of SECs per 100 secondary schools which is defined as the intensity of SECs. The highest concentrations of SECs are in Ankara and Istanbul with over 60 SECs per 100 secondary schools. Izmir, Bursa, Antalya, Mersin, Adana, Kocaeli, Denizli, Aydın, Tekirdağ, Osmaniye, Mardin are the other provinces with high concentration of SECs. They are mostly located in the west of the country except Osmaniye and Mardin. The provinces with low concentration of SECs are Ardahan, Gümüşhane, Bayburt, Kilis, Çankırı, Sinop and Bingöl where the number of SECs is substantially less than that of the secondary schools. These provinces are located mostly in the east and southeast of the country except Çankırı and Sinop.

Take in Table 4

Table 5 shows the distribution of the SECs, secondary schools and the secondary school age (14-17) children of Turkey among the provinces. This table gives idea about the SEC and secondary school opportunities available to the secondary school age children in the provinces. The provinces are listed according to their share of SECs in Turkey's total from the highest to the lowest. For example, Istanbul has by far the highest share of SECs among all of the provinces of Turkey. 
Istanbul houses about 18 percent of the total SECs in Turkey and 12 percent of the secondary schools of Turkey while about 17 percent of secondary school age children of Turkey lives in Istanbul. Thus, we can say that the share of the secondary schools in Istanbul is lower compared to the share of the secondary school age children. Ankara houses about 10 percent of the SECs and about 6 percent of the secondary schools of Turkey while about 6 percent of the secondary school age children of Turkey. The share of secondary schools in Ankara seems commensurate with its share of secondary school age children. However, Ankara is singled out as the province with 15 percent of the total SECs serving only 6 percent of the total secondary school age children.

At the other extreme, Şanlıurfa, Diyarbakır, Gaziantep, Van, Adıyaman and Batman have smaller shares of the SECs and secondary schools than their shares of the secondary school age children. These provinces have relatively high shares of the Turkey's secondary school age children in the order of 2-3 percent of the total. Therefore it would seem sensible to increase the number of secondary schools and possibly SECs in these provinces. The last ten provinces in this table seem to have the shares of secondary schools commensurate with their shares of secondary school age children but their shares of SECs are lower than their shares of children. Thus SECs could possibly be increased in these provinces. However, opening up SECs may not be a profitable business in these provinces. These provinces are mostly located in the east and south east of the country except Çankırı, Bartın and Sinop.

Take in Table 5

We could also note that some of the provinces located in the east and southeast of Turkey such as Hakkari, Şırnak, Bitlis, Siirt, Ağrı, Muş all have somewhat large 
share of the secondary school age children which are slightly higher than their shares of secondary schools and/or shares of SECs. The median number of the SECs is 24 per province and the median number of the secondary schools is 80 per province. In general we observe a more unequal provincial distribution of the SECs (with mean 48 and standard deviation 150) compared to that of the secondary schools (with mean 120 and standard deviation 91). This implies that the distribution of the SECs is more unequal than that of the secondary schools across the provinces of Turkey. Naturally, this has spacial equity implications in their provision across the provinces.

\subsection{Main Characteristics of SECs and Secondary Schools by Provinces}

Table 6 gives the distribution of the number of students and teachers of the SECs across the provinces as well as the number of students per SEC, number of students per teacher in SEC and finally in the last column the number of SEC students per secondary school students. Considering column three we see that there is no obvious pattern to the number of students per SEC. For Turkey general the average number of students per SEC is 332. Those provinces with students larger than this can be considered large and less than 332 can be considered small. With this in mind, there are 48 provinces with SECs larger than Turkey's average and 33 provinces with SECs smaller than Turkey's average. The SECs with 500 or more students per SEC are in Batman, Bayburt, Düzce, Karaman, Kilis and Niğde.Among these provinces three of which, Düzce, Karaman and Niğde are located in the western part of the country. Considering the number of studenst per teacher in the SECs in the fourth column of Table 6 , we observe that in some provinces there are more than 30 students per teacher. They are Artvin, Batman, Bayburt, Bingöl, Bitlis, Çankırı, 
Karabük, Karaman, Kilis, Mardin, Mersin, Muş, Sakarya, Şırnak, Van and Yozgat.Some of these provinces are located in the east and some of them are located in the west. Among these provinces Batman, Bayburt, Bingöl, Düzce, Karaman, Kilis, Niğde and Van are the provinces with both over- crowded SECs and more studenst per teacher. These considerations imply that the quality of the SECs in these provinces may not be very good due to overcrowding of the SECs and the large class sizes.

Next we address the following question: What is the percentage of secondary school students attending SECs in each province? This is given in the last column of Table 6. In Turkey on average 27 percent of the secondary school students attend SECs. Ardahan and Hakkari are the provinces with the smallest percentage which are 9 and 8 percents respectively. It is remarkable that Van is the province with highest (55 percent) of its secondary school students attending an SEC. This is cruious and one wonders if this is related in any way to the earthquake experience in Van two years ago and the ensuing campaign of relief to Van. Van is followed by Balıkesir (38 percent) Çanakkale (39 percent), Denizli (38 percent), Eskişehir (39 percent), Kirklareli (38 percent) and Mersin (40 percent).

Take in Table 6

Following are the provinces that send 20 percent less of their secondary school students to SECs: Adıyaman, Ağrı, Aksaray, Ardahan, Bingöl, Bitlis, Çankırı, Diyarbakır, Gaziantep, Hakkari, Kars, Muş, Siirt, Sivas, Şanlıurfa and Şırnak. Among these provinces following have more than 30 students per teacher: Artvin, Batman, Bayburt, Bingöl, Bitlis, Çankırı, Düzce, Muş and Şırnak. That is, in those provinces with 20 percent or less secondary school students attending SECs, the 
SEC classes are overcrowded. That is, they have more than 30 students per teacher. Ministry of National Education officers and inspectors must pay attention to the SECs in particular in these provinces.

Table 7 gives the distribution of the number of students and teachers of the secondary schools across the provinces as well as the number of students per secondary school, number of students per teacher in secondary schools, number of children scondary school age of 14-17 and finally in the last column the number of secondary school students per secondary school age children. Considering first the number of students per secondary school, the average for Turkey is 492 . Following provinces have 600 or more students per school: Adana, Adiyaman, Batman, Diyarbakır, Gaziantep, Hatay, Istanbul, Mardin, Şanlıurfa and Şırnak. There is no information about the physical capasity or the infrastructure of these secondary schools but, these seem to be rather large schools. The following provinces have 500-599 students per seconday school: Ankara, Antalya, Bingöl, Elazı̆̆g, Hakkari, Izmir, Kocaeli, Mersin and Van. Next we look at the number of students per teacher at the secondary schools. The average for Turkey is 20 students per teacher. Batman, Hakkari, Mardin, Şanlıurfa and Şırnak are the provinces with number of students per teacher 30 or more. Following are the provinces with number of students per teacher is 25-29: Ağr1, Diyarbakır, Gaziantep, Istanbul and Siirt. The provinces with the lowest number of students per teacher are Tunceli (12 students), Burdur (13 students), Isparta (13 students), Karabük (13 students), Çanakkale (14 students) Edirne (14 students) and Sinop (14 students). Those provinces with over 25 students per teacher should be given attention by the Ministry of National Education. Take in Table 7 
Finally, in the last column we examine the number of secondary school students per population of secondary school age children. This gives a measure of enrollment rate in each province for the age group 14-17. There are about 30 provinces with enrollment rate over 100 . However there are also several provinces where substantially small percent of the secondary school age group are not enrolled in secondary schools. Ağrı (48 percent) and Van (46 percent) are the two provinces with less than 50 percent of the age group are enrolled in secondary school. The provinces with $50-75$ percent enrollmet rate are Aksaray ( 75 percent), Bitlis (62 percent), Diyarbakır (75 percent), Iğdır (73 percent), Kars (65 percent), Mardin (73 percent), Muş (53 percent), Siirt (70 percent), Şanlıurfa (56 percent) and Şırnak (65 percent. Raising the rate of secondary school enrollment of 14-17 year groups in these provinces will probably lead to a reduction in their involvement in terror organizations.

As remarked in Section 2, during the academic year of 2012-2013 the compulsory level of schooling is increased to 12 years covering the secondary schools and the data in this section pertains to the academic year of 2011-2012. However, it is doubtful if in some provinces the physical capasity will allow enrolments of all of this age group. Therefore, the Ministry of National Education should pay special attention to those provinces where infrastructure and teachers may be lacking.

In conclusion we can say that the provinves where the quality of of secondary school is low ( 30 or more students per teacher) are Batman, Hakkari, Mardin, Şanlıurfa and Şırnak.(Others are Ağrı, Diyarbakır, Gaziantep, Istanbul and Siirt). The five provinces have the worst secondary school quality. Therefore we will 
examine them in more detail below. They are also the provinces where the schools are overcrowded ( Batman (929), Hakkari (575), Mardin (718), Şanlıurfa (637) and Şırnak (644) among several other provinces. When we consider these five provinces in terms of their equipment with SECs we observe the following. First of all, these provinces have relatively low number of SECs per secondary school within the range of 31-43 percent, although they are not the ones with lowest percentages ofSECs per secondary school. The lowest percentages are for Ardahan (8), Bayburt (12), and Kilis (14). Second, these five provinces have relatively high share of the Turkey's secondary school age children (14-17) but lesser percentage of the Turkey's secondary schools and SECs. Third, these five provinces have relatively low (but not necessarily the lowest) percentages of the secondary school students who are attending SECs. These percetages are as follows: Batman (22), Hakkari (8), Mardin (24), Şanlıurfa (18), Şırnak (20). Further, these five provinces are further disadvantaged in terms of the enrollment rate in a secondary school of the relevant age group of 14-17 years. The percentages of the age group who are enrolled are as follows: Batman (83), Hakkari (86), Mardin (73), Şanlıurfa (56), Şırnak (65). In these five provinces the number of secondary schools and teachers should be increased improving the quality of the schools as well as building more schools to reduce the overcrowding in the schools. In order to increase the quality of the schools the number of students per teacher should be reduced by incerasing the number of teachers. Further, SECs could be encouraged to open up more businesses to increase the proportion of the secondary school students attending SECs. Also students in those provinces could be given scholarships to attend SECs.

\section{Future Prospects}


In March 2012 the prime Minister announced that the university entrance examinations will be eliminated and that the SECs will be closed down (Haber-Türk Newspaper, 2012; Hürriyet Newspaper, 2012 and Milliyet Newspaper, 2012). This has created a series of discussions in the print media and the TVs. As remarked in Section 2, on July 3, 2013, the Minister of National Education announced that starting in 2014 the SBS will be eliminated and the SECs will be closed. Further 5 percent of the SECs which have a suitable infrastructure will be converted to private high schools. All of this was very confusing for the parents who had already registered their children to the SECs and for the SECs which had signed contracts with their teachers. Again there were many discussions at prime times on the national TVs and the national print media all over the country. The educators from the universities and the president of ÖZ-DE-BİR and representatives from the NGOs such as from ERG participated in these debates. The president of ÖZ-DE-BİR, in one of his talks remarked that currently the private high schools are operating with 50 percent of their student capacity and if some of the SECs are converted to private high schools there may not be enough demand for them.

It is also pointed out in the debates that the closure of the SECs will cause at least 80 thousand people (52 thousand teachers and 30 thousand other personnel) become unemployed as well as the loss of the businesses and the income generated and the tax revenue lost. This will harm the national economy. Further if SECs are closed they will reappear under different names and forms. They may even have to go underground and continue to function unregistered, pay no taxes and not be subject to monitoring by the inspectors of the Ministry of National education. 
Currently, there are wide differences in the quality of secondary schools in the country as discussed in detail in Section 2.1. As a result there is a high demand for the high quality, elite "special" high schools because their graduates perform better at the university entrance examinations and get placed at the high quality "prestigious" universities which are in high demand. The graduates of these universities go on to be successful in the labor market, at the governmental positions and the society. Therefore it is the opinion of the present writer that as long as there are quality differences among the secondary schools and among the universities there will be selection examinations determining the transitions at both levels and demand for the SECs which will help students to prepare for the selection examinations. SBS could be eliminated as announced but inevitably there will be other examinations as long as there are school quality differences.

The president of ÖZ-DE-BİR stated that not all attendees of the SECs are preparing for the national examinations. There are many students who are attending SECs for the purposes of getting support for their school classes. Therefore even if the examinations are eliminated there will still be demand for the services of SECs. The president further argued the functions of the SECs and the schools are different. The SECs are not substitutes for school classes but they complement the school classes. It was also made clear in the TV debates that that the counseling and guidance services provided at the SECs are much better than those at schools. Such services cover dealing with examination stress, personal development, developing efficient work habits, selection of the study fields, and selection of the universities together with emphasis on the importance of selecting an occupation. 
It is true that SECs concentrate on preparing the students for the national examinations and teach multiple choice question answering techniques in the shortest possible time. For this reason development of students in the subjects that are not covered in examinations such as sports, arts, music and foreign languages are hindered during the valuable high school years except for the students who major in foreign languages in the high schools. The lack of foreign language skills is especially noticeable among high school graduates. The anecdotal evidence shows the inefficiency in foreign language teaching at secondary schools as students and teachers overlook the language classes since foreign languages are not covered in the university entrance examinations except for those who will continue to major in languages. . Even the students from elite "special" high schools (most of which teach in a foreign language, mostly in English) spend a year of intensive instruction in English if they are admitted to a university with English medium of instruction. Anecdotal evidence also shows that such students prefer to take a year of "rest" by attending English preparatory school after years of fierce race of preparing for the university entrance examination. This is indeed a waste and misuse of scarce public funds both at the high school level and at the universities. Both the Ministry of National education and the YÖK must devise ways to deal with this problem.

The Ministry of National Education sees the future of SECs in their conversion to private high schools in the long-run. The president of ÖZ-DE-BİR- sees the future of SECs in providing services for life-long education in the long-run (ÖZ-DE-BİR, 2013).

\section{Conclusions}


This study provides a discussion of the various aspects of supplementary education in Turkey including a consideration of the various implications of provincial distribution of SECs, of the secondary schools and of the secondary school age (1417) children. We investigate and compare their main characteristics of these distributions. These comparisons give an idea about the spatial equity in the respective distributions of SECs and of the secondary schools across the provinces. The median number of SECs is 24 and that of the secondary schools is 119 per province. However standard deviation of the distribution of SECs is much larger than that of the secondary schools. Thus, there is more inequality in provincial distribution of the SECs than that of the secondary schools as indicated by their respective standard deviations.

The number of students per teacher in the secondary schools is an important indicator of the quality of these schools. Wide variation in this indicator is an aspect that can be addressed by the Ministry of National Education. The high number of students per teacher in Batman, Hakkari, Mardin, Şanlıurfa and Şırnak indicate that they are the five provinces with worst secondary school quality. The other provinces are Ağrı, Diyarbakır, Gaziantep, Istanbul and Siirt. We further considered the other characteristics of these five provinces. First of all, these five provinces have relatively low (but not necessarily the lowest) number of SECs per secondary school. Second, these five provinces have relatively high share of Turkey's secondary school age children but smaller percentage of the Turkey's secondary schools and SECs. Third, these five provinces have relatively low (but not necessarily the lowest) percentages of the secondary school students who are attending SECs. Further, these five provinces are disadvantaged (not necessarily the 
worst) in terms of the enrollment rate in a secondary school of the relevant age group in particular, Şanlıurfa and Şırnak. Raising the rate of secondary school enrollment of 14-17 year old groups in these five provinces will reduce the likelihood of their involvement in terror organizations. In these five provinces the number of secondary school teachers should be increased improving the quality of the schools as well as building more schools to reduce the overcrowding in the schools. Further SECs could be encouraged to open up more businesses to make their numbers more commensurate with these five provinces' share of Turkey's seconday school age children. Also students in these five provinces could be given scholarships to attend SECs. These provinces are located in the southeast of Turkey, However there are several provinces located in the middle or westen part of the country that may have unfavorable indicators also. The number of students per teacher in the SECs is larger than in the secondary schools. That is most of the SEC classes, located in southeast and east and also in the west and middle are overcrowded with more than 30 students per teacher. Ministry of National Education officers and inspectors must pay attention to the SECs in particular, in these provinces.

The high demand for supplementary education has its roots at the national selection examinations for transitions to the secondary schools and the universities Those who receive supplementary education will be able to go to better secondary schools and prestigious universities and finally succeed in the labor market with high paying jobs and may reach influential positions in the government and in the society. 
Students attending SECs learn techniques of answering multiple-choice questions in a short period of time rather than develop abilities and skills to analyze and interpret. The lack of foreign language skills is especially noticeable for high school graduates. The authorities of the Ministry of National Education must pay attention to the lack of foreign language skills of the high school graduates. YÖK must devise ways to prevent misuse of English preparatory schools at the universities leading to waste of public funds.

In order to improve the quality of the high schools and reduce the differences between them voucher system could be implemented. It is believed to increase the competition among the high schools and improve quality and cost efficiency although there are opponents of the voucher system for philosophical and other reasons. School vouchers are subsidies given to parents for to use at any school. In the voucher system government gives the parents a voucher which can be redeemed at a school of their choice. The system can be restricted to public schools or can include private schools as well. The voucher covers children's tuition (that is, the expenditure incurred by the government), either fully or partially. This system encourages competition among schools and gives them incentive to do better. Only schools which can attract more vouchers (thus students) get the means to expand and hire better teachers. Those which fail to attract parents (thus the students) shrink or even be forced to close. Vouchers are like food stamps in the USA but they can be 
used only for formal education instead of food items ${ }^{1}$.

The voucher system is being implemented in the various cities in the USA, Europe, Pakistan, Chile, Ireland, Sweden and the Netherlands among other countries. There is a large literature on the implementation and effectiveness of the voucher system. These must be carefully studied and investigated by the Ministry of National Education for possible implementation in Turkey.

It has been suggested that supplementary education contributes to social stratification and inequalities in the society since attending SECs depends closely on household income and parental education. However, ÖZ-DE-BİR officials argued that SECs provide services for the middle and low income families at affordable prices in contrast to the wealthy who could afford one-to-one private instruction for their children. In order to have a better understanding of this issue, for future research, the socio-economic backgrounds of the SEC participants must be carefully studied. It is the opinion of the present author that the Ministry of National Education must expend resources to improve the quality of education at the secondary schools all over the country but, especially in the east and the southeast. Further, annual examinations could be introduced at the schools while redesigning the national examination systems to increase their dependence on the school curriculums. These will contribute towards better (but not complete) provision of equitable opportunities than the current systems.

\footnotetext{
${ }^{1}$ The educational voucher system is also like the payment of medicine expenses by the Social Security Organization (SGK). A person with a doctor's prescription can go to any pharmacy of his/her choice and get the medicine after paying a contribution. The SGK guarantees the pharmacy for the payment of the prescription. Of course this is a simplified example and the educational voucher system is more complicated. For this reason its implementation requires substantial preliminary studies. Precisely for this ground even in the USA its implementation took a long time and although the coverage is increasing, so far it is observed only in a few cities and states.
} 
Table 1: Recent Trends in Supplementary Education Centers, Students and Teachers, 1975-2012, Turkey.

\begin{tabular}{|c|c|c|c|c|c|c|}
\hline Years & Number of SEC & $\begin{array}{l}\text { Number of SEC } \\
\text { Students }\end{array}$ & $\begin{array}{l}\text { Number of SEC } \\
\text { Teachers }\end{array}$ & $\begin{array}{l}\text { Number of } \\
\text { Students Per SEC }\end{array}$ & $\begin{array}{l}\text { Number of } \\
\text { Teachers Per SEC }\end{array}$ & $\begin{array}{l}\text { Number of } \\
\text { Students Per } \\
\text { Teacher in SEC }\end{array}$ \\
\hline $1975-1976$ & 157 & 45582 & 1384 & 290 & 8.8 & 32.9 \\
\hline 1980-1981 & 174 & 101703 & 3826 & 585 & 22.0 & 26.6 \\
\hline 1990-1991 & 762 & 188407 & 8723 & 247 & 11.4 & 21.6 \\
\hline 1995-1996 & 1292 & 334270 & 10941 & 259 & 8.5 & 30.6 \\
\hline $2000-2001$ & 1920 & 556282 & 17300 & 290 & 9.0 & 32.2 \\
\hline 2001-2002 & 2122 & 608716 & 19881 & 287 & 9.4 & 30.6 \\
\hline 2002-2003 & 2568 & 668673 & 23730 & 260 & 9.2 & 28.2 \\
\hline 2003-2004 & 2984 & 784565 & 30537 & 263 & 10.2 & 25.7 \\
\hline 2004-2005 & 3570 & 925299 & 41031 & 259 & 11.5 & 22.6 \\
\hline 2005-2006 & 3986 & 1071827 & 47621 & 269 & 11.9 & 22.5 \\
\hline 2006-2007 & 4031 & 1122861 & 48855 & 279 & 12.1 & 23.0 \\
\hline $2007-2008$ & 4262 & 1178943 & 51916 & 277 & 12.2 & 22.7 \\
\hline 2008-2009 & 4193 & 1174860 & 50432 & 280 & 12.0 & 23.3 \\
\hline $2009-2010$ & 4099 & 1234738 & 50209 & 301 & 12.2 & 24.6 \\
\hline 2010-2011 & 3961 & 1219472 & 50163 & 308 & 12.7 & 24.3 \\
\hline 2011-2012 & 3858 & 1280297 & 51522 & 332 & 13.4 & 24.8 \\
\hline
\end{tabular}

Source: 1975-1996: Oz-de-bir

2000-2006: Ministry of National Education (2006; 2007)

2008-2012: Ministry of National Education (2013 and various years). 
Table 2: Recent Trends in Secondary Schools, Students and Teachers, 1975-2013, Turkey.

\begin{tabular}{|c|c|c|c|c|c|c|c|}
\hline \multirow[b]{2}{*}{ Years } & \multirow[b]{2}{*}{$\begin{array}{l}\text { Number of } \\
\text { Secondary } \\
\text { Schools }\end{array}$} & \multicolumn{2}{|c|}{$\begin{array}{c}\text { Number of Secondary } \\
\text { Schools }\end{array}$} & \multirow{2}{*}{$\begin{array}{l}\text { Number of } \\
\text { Secondary } \\
\text { Schools } \\
\text { Teachers }\end{array}$} & \multirow{2}{*}{$\begin{array}{l}\text { Number of } \\
\text { Students } \\
\text { per } \\
\text { Secondary } \\
\text { School }\end{array}$} & \multirow{2}{*}{$\begin{array}{l}\text { Number of } \\
\text { Teachers } \\
\text { per } \\
\text { Secondary } \\
\text { School }\end{array}$} & \multirow{2}{*}{$\begin{array}{c}\text { Number of } \\
\text { Students } \\
\text { per Teacher } \\
\text { in } \\
\text { Secondary } \\
\text { School }\end{array}$} \\
\hline & & Graduates & Students & & & & \\
\hline $1975-1976$ & 2110 & 176998 & 773436 & 21079 & 367 & 10.0 & 36.7 \\
\hline 1980-1981 & 3031 & 210370 & 1054937 & 75303 & 348 & 24.8 & 14.0 \\
\hline 1990-1991 & 3743 & 343548 & 1426632 & 112775 & 381 & 30.1 & 12.7 \\
\hline 1995-1996 & 4987 & 551124 & 2162865 & 145241 & 434 & 29.1 & 14.9 \\
\hline $1999-2000$ & 6000 & 536124 & 2316350 & 143379 & 386 & 23.9 & 16.2 \\
\hline $2000-2001$ & 6291 & 532952 & 2362653 & 139969 & 376 & 22.2 & 16.9 \\
\hline 2001-2002 & 6367 & 507363 & 2579819 & 144884 & 405 & 22.8 & 17.8 \\
\hline 2002-2003 & 6212 & 530259 & 3023602 & 137956 & 487 & 22.2 & 21.9 \\
\hline 2003-2004 & 6408 & 683350 & 3014392 & 147776 & 470 & 23.1 & 20.4 \\
\hline 2004-2005 & 6816 & 590834 & 3039449 & 167614 & 446 & 24.6 & 18.1 \\
\hline 2005-2006 & 7435 & 645328 & 3258254 & 185317 & 438 & 24.9 & 17.6 \\
\hline 2006-2007 & 7934 & 729535 & 3386717 & 187665 & 427 & 23.7 & 18.0 \\
\hline 2007-2008 & 8280 & 321741 & 3245322 & 191041 & 392 & 23.1 & 17.0 \\
\hline 2008-2009 & 8675 & 548894 & 3837164 & 196713 & 442 & 22.7 & 19.5 \\
\hline 2009-2010 & 8912 & 662894 & 4240139 & 206862 & 476 & 23.2 & 20.5 \\
\hline 2010-2011 & 9281 & 706512 & 4748610 & 222705 & 512 & 24.0 & 21.3 \\
\hline 2011-2012 & 9672 & 712702 & 4756286 & 235814 & 492 & 24.4 & 20.2 \\
\hline $2012-2013$ & 10418 & - & 4995623 & 254895 & 480 & 24.5 & 19.6 \\
\hline $2011-2012^{b}$ & 4171 & 380548 & 2666066 & 122716 & 639 & 29.4 & 21.7 \\
\hline $2012-2013^{b}$ & 4214 & - & 2725972 & 119393 & 647 & 28.3 & 22.8 \\
\hline
\end{tabular}

Notes : a: The number of secondary schools, students and teacher provided in this table include all kinds of general and vocational and technical high schools.

b: These statistics refer only to the general high schools for the period 2011-2013.

Sources: 1975-1976, 1980-1981: SIS (1991), Table IV-3, Table IV-4.

1990-1991: SIS (1997), Table 109.

1999-2007: Ministry of National Education (2007), Table 1.6

2007-2013: Ministry of National Education (2013 and various years). 
Table 3: Number of Students in Supplementary Education Centers and Number of Secondary School ${ }^{\mathrm{a}}$ Graduates by Gender, 2000-2012, Turkey.

\begin{tabular}{|c|c|c|c|c|c|c|}
\hline \multirow[b]{2}{*}{ Years } & \multicolumn{3}{|c|}{$\begin{array}{l}\text { Number of Students in Supplementary Education } \\
\text { Centers }\end{array}$} & \multicolumn{3}{|c|}{ Number of Secondary School Graduates } \\
\hline & Total & Male (\%) & Female (\%) & Total & Male (\%) & Female (\%) \\
\hline $2000-2001$ & 556282 & $308157(55.4)$ & $248125(44.6)$ & 532952 & $302530(56.8)$ & $230422(43.2)$ \\
\hline 2001-2002 & 608716 & $331330(54.4)$ & $277386(45.6)$ & 507363 & $280252(55.2)$ & $227111(44.8)$ \\
\hline $2002-2003$ & 668673 & $361503(54.1)$ & 301170 (45.9) & 530259 & $292670(55.2)$ & $237589(44.8)$ \\
\hline 2003-2004 & 784565 & $420979(53.7)$ & $363586(46.3)$ & 683350 & $376730(55.1)$ & 306620 (44.9) \\
\hline 2004-2005 & 935299 & $491408(53.1)$ & 433891 (46.9) & 590834 & $321847(54.5)$ & $268987(45.5)$ \\
\hline 2005-2006 & 1071827 & $562916(52.5)$ & $508911(47.5)$ & 645328 & $352384(54.6)$ & $292944(45.4)$ \\
\hline 2006-2007 & 1122861 & $584369(52.0)$ & $538492(48.0)$ & 729535 & $401916(55.1)$ & 327619 (44.9) \\
\hline $2007-2008$ & 1178943 & 609394 (51.7) & $569549(48.3)$ & 321741 & 182058 (56.6) & $139683(43.4)$ \\
\hline 2008-2009 & 1174860 & $600903(51.1)$ & 573957 (48.9) & 548894 & $264988(48.3)$ & 283906 (51.7) \\
\hline 2009-2010 & 1234738 & $624212(50.6)$ & $610526(49.4)$ & 662894 & 342017 (51.6) & 320877 (48.4) \\
\hline 2010-2011 & 1219472 & 613968 (50.3) & 605504 (49.7) & 706512 & 360783 (51.1) & 345729 (48.9) \\
\hline 2011-2012 & 1280297 & 644059 (50.3) & 636238 (49.7) & 712702 & 355457 (49.9) & 357245 (50.1) \\
\hline
\end{tabular}

Notes : a: The number of secondary schools, students and teacher provided in this table include all kinds of general and vocational and technical high schools.

Source: Ministry of National Education (2006; 2007, 2013 and various years). 
Table 4: Distribution of Supplementary Education Centers and Secondary Schools by Provinces, 2011-2012, Turkey"

\begin{tabular}{|c|c|c|c|}
\hline Provinces ${ }^{b}$ & $\begin{array}{l}\text { Number } \\
\text { of SEC (a) }\end{array}$ & $\begin{array}{c}\text { Numbe } \\
\text { r of } \\
\text { Second } \\
\text { ary } \\
\text { School } \\
s^{a} \text { (b) }\end{array}$ & $\begin{array}{l}a / b \\
(\%)\end{array}$ \\
\hline Istanbul & 710 & 1179 & 60.2 \\
\hline Ankara & 384 & 590 & 65.1 \\
\hline Izmir & 206 & 459 & 44.9 \\
\hline Bursa & 147 & 303 & 48.5 \\
\hline Antalya & 124 & 230 & 53.9 \\
\hline Mersin & 117 & 204 & 57.4 \\
\hline Adana & 115 & 230 & 50.0 \\
\hline Konya & 84 & 303 & 27.7 \\
\hline Hatay & 82 & 148 & 55.4 \\
\hline Kocaeli & 77 & 212 & 36.3 \\
\hline Denizli & 76 & 135 & 56.3 \\
\hline Manisa & 74 & 213 & 34.7 \\
\hline Balıkesir & 73 & 183 & 39.9 \\
\hline Aydın & 67 & 137 & 48.9 \\
\hline Kayseri & 67 & 178 & 37.6 \\
\hline Samsun & 61 & 172 & 35.5 \\
\hline Şanlıurfa & 58 & 144 & 40.3 \\
\hline Diyarbakır & 54 & 133 & 40.6 \\
\hline Muğla & 53 & 119 & 44.5 \\
\hline Gaziantep & 47 & 154 & 30.5 \\
\hline Tekirdağ & 47 & 104 & 45.2 \\
\hline Trabzon & 47 & 133 & 35.3 \\
\hline Malatya & 43 & 125 & 34.4 \\
\hline Kahramanmaraş & 42 & 134 & 31.3 \\
\hline Eskişehir & 41 & 114 & 36.0 \\
\hline Sakarya & 37 & 142 & 26.1 \\
\hline Erzurum & 36 & 118 & 30.5 \\
\hline
\end{tabular}

\begin{tabular}{|c|c|c|c|}
\hline Provinces & $\begin{array}{c}\text { Number of } \\
\text { SEC (a) }\end{array}$ & $\begin{array}{l}\text { Numbe } \\
\text { r of } \\
\text { Second } \\
\text { ary } \\
\text { School } \\
\text { s (b) }\end{array}$ & $\begin{array}{l}a / b \\
(\%)\end{array}$ \\
\hline Afyonkarahisar & 35 & 125 & 28.0 \\
\hline Osmaniye & 35 & 67 & 52.2 \\
\hline Çanakkale & 33 & 106 & 31.1 \\
\hline Mardin & 33 & 76 & 43.4 \\
\hline Zonguldak & 33 & 98 & 33.7 \\
\hline Sivas & 31 & 103 & 30.1 \\
\hline Ordu & 30 & 104 & 28.8 \\
\hline Çorum & 29 & 86 & 33.7 \\
\hline Isparta & 29 & 101 & 28.7 \\
\hline Elazığ & 28 & 85 & 32.9 \\
\hline Adiyaman & 25 & 80 & 31.3 \\
\hline Amasya & 25 & 70 & 35.7 \\
\hline Kütahya & 24 & 114 & 21.1 \\
\hline Tokat & 24 & 102 & 23.5 \\
\hline Edirne & 23 & 75 & 30.7 \\
\hline Yozgat & 22 & 115 & 19.1 \\
\hline Kırklareli & 21 & 55 & 38.2 \\
\hline Uşak & 21 & 51 & 41.2 \\
\hline Giresun & 20 & 101 & 19.8 \\
\hline Van & 19 & 94 & 20.2 \\
\hline Batman & 17 & 47 & 36.2 \\
\hline Rize & 17 & 76 & 22.4 \\
\hline Kırıkkale & 16 & 56 & 28.6 \\
\hline Bolu & 15 & 53 & 28.3 \\
\hline Burdur & 15 & 54 & 27.8 \\
\hline Kastamonu & 15 & 76 & 19.7 \\
\hline Kırşehir & 15 & 52 & 28.8 \\
\hline
\end{tabular}

\begin{tabular}{|c|c|c|c|}
\hline Provinces & $\begin{array}{l}\text { Number } \\
\text { of SEC (a) }\end{array}$ & $\begin{array}{l}\text { Numbe } \\
\text { r of } \\
\text { Second } \\
\text { ary } \\
\text { School } \\
\text { s (b) }\end{array}$ & $\begin{array}{l}a / b \\
(\%)\end{array}$ \\
\hline Aksaray & 14 & 61 & 23.0 \\
\hline Hakkari & 14 & 39 & 35.9 \\
\hline Nevşehir & 14 & 60 & 23.3 \\
\hline Şırnak & 14 & 46 & 30.4 \\
\hline Bitlis & 13 & 53 & 24.5 \\
\hline Siirt & 12 & 45 & 26.7 \\
\hline Ağrı & 11 & 55 & 20.0 \\
\hline Bilecik & 11 & 53 & 20.8 \\
\hline Karabük & 11 & 44 & 25.0 \\
\hline Muş & 11 & 54 & 20.4 \\
\hline Artvin & 10 & 44 & 22.7 \\
\hline Niğde & 10 & 59 & 16.9 \\
\hline Yalova & 10 & 36 & 27.8 \\
\hline Düzce & 9 & 51 & 17.6 \\
\hline Erzincan & 9 & 54 & 16.7 \\
\hline Karaman & 9 & 44 & 20.5 \\
\hline Kars & 9 & 38 & 23.7 \\
\hline Sinop & 9 & 58 & 15.5 \\
\hline Bartın & 7 & 35 & 20.0 \\
\hline Iğdır & 7 & 28 & 25.0 \\
\hline Bingöl & 6 & 35 & 17.1 \\
\hline Çankırı & 5 & 43 & 11.6 \\
\hline Tunceli & 4 & 26 & 15.4 \\
\hline Gümüşhane & 3 & 30 & 10.0 \\
\hline Kilis & 3 & 21 & 14.3 \\
\hline Ardahan & 2 & 25 & 8.0 \\
\hline Bayburt & 2 & 17 & 11.8 \\
\hline Turkey & 3858 & 9672 & 39.9 \\
\hline
\end{tabular}

Notes: a: The number of secondary schools, students and teacher provided in this table include all kinds of general and vocational and technical high schools.

bThe provinces are ordered by $t$ he number of supplementary education centers they have from highest to the lowest

A table similar to Table 4 for the academic year 2005-2006 is provided in Tansel and Bircan (2007) with the exception that it deals with the number of high schools rather than secondary schools.

Source: The numbers of SECs for the provinces are obtained from the Ministry of National Education. The numbers of secondary schools are from Ministry of National Education (2013). 
Table 5: Distribution of the Supplementary Education Centers, Secondary Schools ${ }^{\mathrm{d}}$ and Secondary School Age (1417) Population by Provinces, 2011-2012, Turkey

\begin{tabular}{|c|c|c|c|c|c|c|c|c|c|c|c|}
\hline Provinces ${ }^{\mathrm{e}}$ & $\begin{array}{c}\% \\
\text { Suppleme } \\
\text { ntary } \\
\text { Education } \\
\text { a }\end{array}$ & $\begin{array}{c}\% \\
\text { Second } \\
\text { ary } \\
\text { School } \\
b\end{array}$ & $\begin{array}{c}\% \\
\text { Pop. } \\
\text { c }\end{array}$ & Provinces & $\begin{array}{c}\% \\
\text { Supplemen } \\
\text { tary } \\
\text { Education }\end{array}$ & $\begin{array}{c}\% \\
\text { Second } \\
\text { ary } \\
\text { School } \\
b\end{array}$ & $\begin{array}{c}\% \\
\text { Pop. } \\
\text { c }\end{array}$ & Provinces & $\begin{array}{c}\% \\
\text { Supplem } \\
\text { entary } \\
\text { Educatio } \\
\mathrm{n}^{\mathrm{a}}\end{array}$ & $\begin{array}{c}\% \\
\text { Second } \\
\text { ary } \\
\text { School }\end{array}$ & $\begin{array}{c}\% \\
\text { Pop. } \\
\text { c }\end{array}$ \\
\hline Istanbul & 18.4 & 12.2 & 16.6 & Afyonkarahisar & 0.9 & 1.3 & 0.9 & Aksaray & 0.4 & 0.6 & 0.6 \\
\hline Ankara & 10.0 & 6.1 & 5.8 & Osmaniye & 0.9 & 0.7 & 0.7 & Hakkari & 0.4 & 0.4 & 0.5 \\
\hline Izmir & 5.3 & 4.7 & 4.4 & Çanakkale & 0.9 & 1.1 & 0.5 & Nevşehir & 0.4 & 0.6 & 0.4 \\
\hline Bursa & 3.8 & 3.1 & 3.2 & Mardin & 0.9 & 0.8 & 1.4 & Şırnak & 0.4 & 0.5 & 0.9 \\
\hline Antalya & 3.2 & 2.4 & 2.6 & Zonguldak & 0.9 & 1.0 & 0.7 & Bitlis & 0.3 & 0.5 & 0.6 \\
\hline Mersin & 3.0 & 2.1 & 2.3 & Sivas & 0.8 & 1.1 & 0.9 & Siirt & 0.3 & 0.5 & 0.6 \\
\hline Adana & 3.0 & 2.4 & 3.0 & Ordu & 0.8 & 1.1 & 1.0 & Ağrı & 0.3 & 0.6 & 1.0 \\
\hline Konya & 2.2 & 3.1 & 2.9 & Çorum & 0.8 & 0.9 & 0.7 & Bilecik & 0.3 & 0.5 & 0.2 \\
\hline Hatay & 2.1 & 1.5 & 2.2 & Isparta & 0.8 & 1.0 & 0.5 & Karabük & 0.3 & 0.5 & 0.2 \\
\hline Kocaeli & 2.0 & 2.2 & 2.0 & Elazığ & 0.7 & 0.9 & 0.8 & Muş & 0.3 & 0.6 & 0.8 \\
\hline Denizli & 2.0 & 1.4 & 1.1 & Adıyaman & 0.6 & 0.8 & 1.0 & Artvin & 0.3 & 0.5 & 0.2 \\
\hline Manisa & 1.9 & 2.2 & 1.6 & Amasya & 0.6 & 0.7 & 0.4 & Niğde & 0.3 & 0.6 & 0.5 \\
\hline Balıkesir & 1.9 & 1.9 & 1.3 & Kütahya & 0.6 & 1.2 & 0.6 & Yalova & 0.3 & 0.4 & 0.2 \\
\hline Aydın & 1.7 & 1.4 & 1.2 & Tokat & 0.6 & 1.1 & 0.9 & Düzce & 0.2 & 0.5 & 0.4 \\
\hline Kayseri & 1.7 & 1.8 & 1.7 & Edirne & 0.6 & 0.8 & 0.4 & Erzincan & 0.2 & 0.6 & 0.3 \\
\hline Samsun & 1.6 & 1.8 & 1.7 & Yozgat & 0.6 & 1.2 & 0.7 & Karaman & 0.2 & 0.5 & 0.3 \\
\hline Şanlıurfa & 1.5 & 1.5 & 3.2 & Kırklareli & 0.5 & 0.6 & 0.4 & Kars & 0.2 & 0.4 & 0.5 \\
\hline Diyarbakır & 1.4 & 1.4 & 2.8 & Uşak & 0.5 & 0.5 & 0.4 & Sinop & 0.2 & 0.6 & 0.2 \\
\hline Muğla & 1.4 & 1.2 & 0.9 & Giresun & 0.5 & 1.0 & 0.5 & Bartın & 0.2 & 0.4 & 0.2 \\
\hline Gaziantep & 1.2 & 1.6 & 2.8 & Van & 0.5 & 1.0 & 2.0 & Iğdır & 0.2 & 0.3 & 0.3 \\
\hline Tekirdağ & 1.2 & 1.1 & 1.0 & Batman & 0.4 & 0.5 & 1.0 & Bingöl & 0.2 & 0.4 & 0.4 \\
\hline Trabzon & 1.2 & 1.4 & 1.0 & Rize & 0.4 & 0.8 & 0.4 & Çankırı & 0.1 & 0.4 & 0.2 \\
\hline Malatya & 1.1 & 1.3 & 1.1 & Kırıkkale & 0.4 & 0.6 & 0.4 & Tunceli & 0.1 & 0.3 & 0.1 \\
\hline Kahramanmaraş & 1.1 & 1.4 & 1.6 & Bolu & 0.4 & 0.5 & 0.3 & Gümüşhane & 0.1 & 0.3 & 0.2 \\
\hline Eskişehir & 1.1 & 1.2 & 0.9 & Burdur & 0.4 & 0.6 & 0.3 & Kilis & 0.1 & 0.2 & 0.2 \\
\hline Sakarya & 1.0 & 1.5 & 1.1 & Kastamonu & 0.4 & 0.8 & 0.4 & Ardahan & 0.1 & 0.3 & 0.2 \\
\hline Erzurum & 0.9 & 1.2 & 1.2 & Kırşehir & 0.4 & 0.5 & 0.3 & Bayburt & 0.1 & 0.2 & 0.1 \\
\hline
\end{tabular}

Notes:

a: Percent of the number of supplementary education centers in a province in the total number of supplementary education centers in Turkey at the end of the academic year 2011-2012.

b: Percent of the number of seconday schools in a province in the total number of seconday schools in Turkey at the beginning of the academic year 2011-2012.

c: Percent of the high school age population (14-17) in a province in the total high school age population of Turkey in December 31, 2012 based on ADNKS .

d: The number of secondary schools, students and teacher provided in this table include all kinds of general and vocational and technical high schools.

e: The provinces are ordered by the number of supplementary education centers they have from highest to the lowest.

A table similar to Table 5 for the academic year 2005-2006 is provided in Tansel and Bircan (2007) with the exception that it deals with the number of high schools rather than secondary schools.

Sources: $a$ and $b$ : The numbers of SECs for the provinces are obtained from the Ministry of National Education. The numbers of secondary schools are from Ministry of National Education (2012). 
Table 6: The Main Characteristics of Supplementary Education Centers in the Provincial Distribution, 2011-2012, Turkey.

\begin{tabular}{|c|c|c|c|c|c|}
\hline & $\begin{array}{l}\text { Number of } \\
\text { SEC Students }\end{array}$ & $\begin{array}{l}\text { Number of } \\
\text { SEC } \\
\text { Teachers }\end{array}$ & $\begin{array}{c}\text { Number of } \\
\text { Students per } \\
\text { SEC }\end{array}$ & $\begin{array}{l}\text { Number of Students } \\
\text { per Teacher in SEC }\end{array}$ & $\begin{array}{c}\text { SEC Students per } \\
\text { Secondary School } \\
\text { Student (\%) }\end{array}$ \\
\hline Adana & 38665 & 1486 & 336.2 & 26.0 & 27.2 \\
\hline Adıyaman & 9199 & 303 & 368.0 & 30.4 & 18.9 \\
\hline Afyonkarahisar & 11714 & 438 & 334.7 & 26.7 & 30.9 \\
\hline Ağrı & 3785 & 146 & 344.1 & 25.9 & 14.9 \\
\hline Aksaray & 4255 & 189 & 303.9 & 22.5 & 19.8 \\
\hline Amasya & 7598 & 251 & 303.9 & 30.3 & 34.4 \\
\hline Ankara & 99205 & 4711 & 258.3 & 21.1 & 31.1 \\
\hline Antalya & 42577 & 1799 & 343.4 & 23.7 & 33.3 \\
\hline Ardahan & 605 & 20 & 302.5 & 30.3 & 9.4 \\
\hline Artvin & 2540 & 78 & 254.0 & 32.6 & 22.9 \\
\hline Aydın & 17695 & 887 & 264.1 & 19.9 & 31.7 \\
\hline Balıkesir & 24109 & 1042 & 330.3 & 23.1 & 37.7 \\
\hline Bartın & 2817 & 119 & 402.4 & 23.7 & 27.0 \\
\hline Batman & 9768 & 259 & 574.6 & 37.7 & 22.4 \\
\hline Bayburt & 1231 & 35 & 615.5 & 35.2 & 22.1 \\
\hline Bilecik & 3603 & 133 & 327.5 & 27.1 & 28.8 \\
\hline Bingöl & 3217 & 94 & 536.2 & 34.2 & 17.5 \\
\hline Bitlis & 3959 & 121 & 304.5 & 32.7 & 19.8 \\
\hline Bolu & 4945 & 218 & 329.7 & 22.7 & 28.1 \\
\hline Burdur & 4779 & 206 & 318.6 & 23.2 & 33.9 \\
\hline Bursa & 46968 & 2205 & 319.5 & 21.3 & 28.1 \\
\hline Çanakkale & 9820 & 372 & 297.6 & 26.4 & 39.4 \\
\hline Çankırı & 1490 & 45 & 298.0 & 33.1 & 14.2 \\
\hline Çorum & 9243 & 361 & 318.7 & 25.6 & 27.9 \\
\hline Denizli & 20675 & 1038 & 272.0 & 19.9 & 38.0 \\
\hline Diyarbakır & 18630 & 690 & 345.0 & 27.0 & 17.1 \\
\hline Düzce & 5331 & 170 & 592.3 & 31.4 & 23.3 \\
\hline Edirne & 7541 & 300 & 327.9 & 25.1 & 36.9 \\
\hline Elazığ & 11405 & 443 & 407.3 & 25.7 & 26.0 \\
\hline Erzincan & 3622 & 126 & 402.4 & 28.7 & 23.0 \\
\hline Erzurum & 11264 & 440 & 312.9 & 25.6 & 23.0 \\
\hline Eskişehir & 18091 & 606 & 441.2 & 29.9 & 38.6 \\
\hline Gaziantep & 22087 & 790 & 469.9 & 28.0 & 20.0 \\
\hline Giresun & 6992 & 313 & 349.6 & 22.3 & 24.0 \\
\hline Gümüşhane & 1365 & 52 & 455.0 & 26.3 & 16.2 \\
\hline Hakkari & 1748 & 64 & 124.9 & 27.3 & 7.8 \\
\hline
\end{tabular}




\begin{tabular}{|c|c|c|c|c|c|}
\hline Hatay & 23636 & 1067 & 288.2 & 22.2 & 25.5 \\
\hline Iğdır & 2883 & 106 & 411.9 & 27.2 & 23.0 \\
\hline Isparta & 9137 & 406 & 315.1 & 22.5 & 35.0 \\
\hline Istanbul & 216645 & 8959 & 305.1 & 24.2 & 23.9 \\
\hline Izmir & 68613 & 2948 & 333.1 & 23.3 & 29.4 \\
\hline Kahramanmaraş & 17255 & 636 & 410.8 & 27.1 & 26.3 \\
\hline Karabük & 4658 & 158 & 423.5 & 29.5 & 33.3 \\
\hline Karaman & 4547 & 153 & 505.2 & 29.7 & 28.8 \\
\hline Kars & 2679 & 105 & 297.7 & 25.5 & 16.8 \\
\hline Kastamonu & 5726 & 202 & 381.7 & 28.3 & 29.4 \\
\hline Kayseri & 24352 & 998 & 363.5 & 24.4 & 28.8 \\
\hline Kırıkkale & 7270 & 205 & 454.4 & 35.5 & 36.0 \\
\hline Kırklareli & 7156 & 290 & 340.8 & 24.7 & 38.2 \\
\hline Kırşehir & 5518 & 219 & 367.9 & 25.2 & 36.4 \\
\hline Kilis & 2375 & 60 & 791.7 & 39.6 & 26.0 \\
\hline Kocaeli & 27538 & 1073 & 357.6 & 25.7 & 24.2 \\
\hline Konya & 34046 & 1181 & 405.3 & 28.8 & 26.8 \\
\hline Kütahya & 8566 & 359 & 356.9 & 23.9 & 25.0 \\
\hline Malatya & 15659 & 619 & 364.2 & 25.3 & 25.8 \\
\hline Manisa & 23085 & 983 & 312.0 & 23.5 & 30.8 \\
\hline Mardin & 13023 & 394 & 394.6 & 33.1 & 23.9 \\
\hline Mersin & 44214 & 1492 & 377.9 & 29.6 & 40.3 \\
\hline Muğla & 14308 & 714 & 270.0 & 20.0 & 31.6 \\
\hline Muş & 4381 & 139 & 398.3 & 31.5 & 20.2 \\
\hline Nevşehir & 3933 & 139 & 280.9 & 28.3 & 24.7 \\
\hline Niğde & 5169 & 176 & 516.9 & 29.4 & 26.4 \\
\hline Ordu & 14036 & 554 & 467.9 & 25.3 & 32.5 \\
\hline Osmaniye & 12049 & 447 & 344.3 & 27.0 & 34.6 \\
\hline Rize & 5802 & 219 & 341.3 & 26.5 & 21.0 \\
\hline Sakarya & 16595 & 525 & 448.5 & 31.6 & 27.8 \\
\hline Samsun & 24407 & 976 & 400.1 & 25.0 & 29.3 \\
\hline Siirt & 3698 & 151 & 308.2 & 24.5 & 17.0 \\
\hline Sinop & 3088 & 127 & 343.1 & 24.3 & 25.4 \\
\hline Sivas & 7870 & 343 & 253.9 & 22.9 & 19.1 \\
\hline Şanlıurfa & 16635 & 692 & 286.8 & 24.0 & 18.1 \\
\hline Şırnak & 5906 & 154 & 421.9 & 38.4 & 19.9 \\
\hline Tekirdağ & 17046 & 668 & 362.7 & 25.5 & 34.0 \\
\hline Tokat & 9705 & 350 & 404.4 & 27.7 & 25.6 \\
\hline Trabzon & 15368 & 584 & 327.0 & 26.3 & 28.5 \\
\hline Tunceli & 1084 & 37 & 271.0 & 29.3 & 24.4 \\
\hline Uşak & 6195 & 311 & 295.0 & 19.9 & 30.7 \\
\hline Van & 9490 & 262 & 499.5 & 36.2 & 55.1 \\
\hline Yalova & 3805 & 190 & 380.5 & 20.0 & 27.2 \\
\hline Yozgat & 6563 & 204 & 298.3 & 32.2 & 22.6 \\
\hline
\end{tabular}




\begin{tabular}{|l|c|c|c|c|c|}
\hline Zonguldak & 12045 & 397 & 365.0 & 30.3 & 33.8 \\
\hline Turkey & 1280297 & 51522 & 331.9 & 24.8 & 27.1 \\
\hline
\end{tabular}

Notes: The number of secondary schools, students and teacher provided in this table include all kinds of general and vocational and technical high schools.

Source: The numbers of SEC students and teachers for the provinces are obtained from the Ministry of National Education. 
Table 7: The Main Characteristics of Secondary Schools in the Provincial Distribution, 2011-2012, Turkey

\begin{tabular}{|c|c|c|c|c|c|c|}
\hline Provinces & $\begin{array}{l}\text { Number of } \\
\text { Secondary } \\
\text { School } \\
\text { Students }\end{array}$ & $\begin{array}{c}\text { Number of } \\
\text { Secondary } \\
\text { School } \\
\text { Teachers }\end{array}$ & $\begin{array}{l}\text { Number of } \\
\text { Students } \\
\text { per } \\
\text { Secondary } \\
\text { School }\end{array}$ & $\begin{array}{c}\text { Number of } \\
\text { Students } \\
\text { per Teacher } \\
\text { in } \\
\text { Secondary } \\
\text { School }\end{array}$ & $\begin{array}{l}\text { Children } \\
\text { Age 14-17 }\end{array}$ & $\begin{array}{c}\text { Secondary } \\
\text { School } \\
\text { Students } \\
\text { per Children } \\
\text { Age 14-17 } \\
(\%)\end{array}$ \\
\hline Adana & 142343 & 6884 & 618.9 & 20.7 & 154392 & 92.2 \\
\hline Adıyaman & 48571 & 2009 & 607.1 & 24.2 & 52131 & 93.2 \\
\hline Afyonkarahisar & 37898 & 2233 & 303.2 & 17.0 & 47964 & 79.0 \\
\hline Ağrı & 25358 & 1033 & 461.1 & 24.5 & 53427 & 47.5 \\
\hline Aksaray & 21516 & 1154 & 352.7 & 18.6 & 28816 & 74.7 \\
\hline Amasya & 22090 & 1466 & 315.6 & 15.1 & 20967 & 105.4 \\
\hline Ankara & 318677 & 18746 & 540.1 & 17.0 & 298167 & 106.9 \\
\hline Antalya & 127859 & 6491 & 555.9 & 19.7 & 131688 & 97.1 \\
\hline Ardahan & 6403 & 395 & 256.1 & 16.2 & 8150 & 78.6 \\
\hline Artvin & 11105 & 646 & 252.4 & 17.2 & 10040 & 110.6 \\
\hline Aydın & 55824 & 3712 & 407.5 & 15.0 & 61469 & 90.8 \\
\hline Balıkesir & 63899 & 4262 & 349.2 & 15.0 & 67106 & 95.2 \\
\hline Bartın & 10444 & 709 & 298.4 & 14.7 & 10781 & 96.9 \\
\hline Batman & 43645 & 1340 & 928.6 & 32.6 & 52701 & 82.8 \\
\hline Bayburt & 5567 & 269 & 327.5 & 20.7 & 5657 & 98.4 \\
\hline Bilecik & 12489 & 773 & 235.6 & 16.2 & 11449 & 109.1 \\
\hline Bingöl & 18398 & 779 & 525.7 & 23.6 & 21421 & 85.9 \\
\hline Bitlis & 19996 & 859 & 377.3 & 23.3 & 32472 & 61.6 \\
\hline Bolu & 17603 & 1144 & 332.1 & 15.4 & 15826 & 111.2 \\
\hline Burdur & 14111 & 1061 & 261.3 & 13.3 & 14694 & 96.0 \\
\hline Bursa & 167368 & 8600 & 552.4 & 19.5 & 166824 & 100.3 \\
\hline Çanakkale & 24944 & 1789 & 235.3 & 13.9 & 24922 & 100.1 \\
\hline Çankırı & 10518 & 709 & 244.6 & 14.8 & 11015 & 95.5 \\
\hline Çorum & 33186 & 1952 & 385.9 & 17.0 & 36261 & 91.5 \\
\hline Denizli & 54439 & 3301 & 403.3 & 16.5 & 58978 & 92.3 \\
\hline Diyarbakır & 108879 & 3865 & 818.6 & 28.2 & 144447 & 75.4 \\
\hline Düzce & 22928 & 1191 & 449.6 & 19.3 & 22593 & 101.5 \\
\hline Edirne & 20437 & 1469 & 272.5 & 13.9 & 20404 & 100.2 \\
\hline Elazığ & 43861 & 2306 & 516.0 & 19.0 & 40747 & 107.6 \\
\hline Erzincan & 15732 & 867 & 291.3 & 18.1 & 14455 & 108.8 \\
\hline Erzurum & 48981 & 2534 & 415.1 & 19.3 & 62372 & 78.5 \\
\hline Eskişehir & 46839 & 2971 & 410.9 & 15.8 & 43950 & 106.6 \\
\hline Gaziantep & 110160 & 3959 & 715.3 & 27.8 & 145448 & 75.7 \\
\hline Giresun & 29082 & 1910 & 287.9 & 15.2 & 27543 & 105.6 \\
\hline Gümüşhane & 8439 & 488 & 281.3 & 17.3 & 9593 & 88.0 \\
\hline Hakkari & 22441 & 657 & 575.4 & 34.2 & 26026 & 86.2 \\
\hline Hatay & 92784 & 4138 & 626.9 & 22.4 & 112950 & 82.1 \\
\hline Iğdır & 12526 & 541 & 447.4 & 23.2 & 17152 & 73.0 \\
\hline
\end{tabular}




\begin{tabular}{|c|c|c|c|c|c|c|}
\hline Isparta & 26111 & 1956 & 258.5 & 13.3 & 24205 & 107.9 \\
\hline Istanbul & 905967 & 33954 & 768.4 & 26.7 & 857824 & 105.6 \\
\hline Izmir & 233576 & 12686 & 508.9 & 18.4 & 226775 & 103.0 \\
\hline Kahramanmaraş & 65697 & 3215 & 490.3 & 20.4 & 82712 & 79.4 \\
\hline Karabük & 13985 & 1048 & 317.8 & 13.3 & 12728 & 109.9 \\
\hline Karaman & 15779 & 813 & 358.6 & 19.4 & 17098 & 92.3 \\
\hline Kars & 15936 & 715 & 419.4 & 22.3 & 24615 & 64.7 \\
\hline Kastamonu & 19508 & 1291 & 256.7 & 15.1 & 20067 & 97.2 \\
\hline Kayseri & 84523 & 4707 & 474.8 & 18.0 & 88932 & 95.0 \\
\hline Kırıkkale & 20183 & 1234 & 360.4 & 16.4 & 18783 & 107.5 \\
\hline Kırklareli & 18711 & 1040 & 340.2 & 18.0 & 18429 & 101.5 \\
\hline Kırşehir & 15153 & 1022 & 291.4 & 14.8 & 15035 & 100.8 \\
\hline Kilis & 9142 & 383 & 435.3 & 23.9 & 10111 & 90.4 \\
\hline Kocaeli & 113764 & 4997 & 536.6 & 22.8 & 102692 & 110.8 \\
\hline Konya & 127047 & 6546 & 419.3 & 19.4 & 148775 & 85.4 \\
\hline Kütahya & 34240 & 1960 & 300.4 & 17.5 & 31899 & 107.3 \\
\hline Malatya & 60578 & 3187 & 484.6 & 19.0 & 55233 & 109.7 \\
\hline Manisa & 74848 & 4496 & 351.4 & 16.6 & 84066 & 89.0 \\
\hline Mardin & 54545 & 1817 & 717.7 & 30.0 & 74590 & 73.1 \\
\hline Mersin & 109605 & 5979 & 537.3 & 18.3 & 120655 & 90.8 \\
\hline Muğla & 45350 & 2788 & 381.1 & 16.3 & 47475 & 95.5 \\
\hline Muş & 21668 & 925 & 401.3 & 23.4 & 40929 & 52.9 \\
\hline Nevşehir & 15906 & 1137 & 265.1 & 14.0 & 19432 & 81.9 \\
\hline Niğde & 19558 & 1238 & 331.5 & 15.8 & 25163 & 77.7 \\
\hline Ordu & 43126 & 2637 & 414.7 & 16.4 & 52708 & 81.8 \\
\hline Osmaniye & 34807 & 1898 & 519.5 & 18.3 & 37643 & 92.5 \\
\hline Rize & 27663 & 1521 & 364.0 & 18.2 & 21209 & 130.4 \\
\hline Sakarya & 59679 & 2896 & 420.3 & 20.6 & 58963 & 101.2 \\
\hline Samsun & 83248 & 4749 & 484.0 & 17.5 & 88329 & 94.2 \\
\hline Siirt & 21730 & 738 & 482.9 & 29.4 & 30897 & 70.3 \\
\hline Sinop & 12160 & 853 & 209.7 & 14.3 & 12108 & 100.4 \\
\hline Sivas & 41237 & 2217 & 400.4 & 18.6 & 43972 & 93.8 \\
\hline Şanlıurfa & 91760 & 2963 & 637.2 & 31.0 & 163309 & 56.2 \\
\hline Şırnak & 29632 & 985 & 644.2 & 30.1 & 45297 & 65.4 \\
\hline Tekirdağ & 50134 & 2271 & 482.1 & 22.1 & 49796 & 100.7 \\
\hline Tokat & 37891 & 2104 & 371.5 & 18.0 & 44850 & 84.5 \\
\hline Trabzon & 53972 & 3251 & 405.8 & 16.6 & 49364 & 109.3 \\
\hline Tunceli & 4445 & 382 & 171.0 & 11.6 & 3889 & 114.3 \\
\hline Uşak & 20207 & 1160 & 396.2 & 17.4 & 21159 & 95.5 \\
\hline Van & 47211 & 2390 & 502.2 & 19.8 & 102683 & 46.0 \\
\hline Yalova & 13979 & 790 & 388.3 & 17.7 & 12867 & 108.6 \\
\hline Yozgat & 29049 & 1614 & 252.6 & 18.0 & 35221 & 82.5 \\
\hline Zonguldak & 35636 & 2049 & 363.6 & 17.4 & 35051 & 101.7 \\
\hline Turkey & 4756286 & 235814 & 491.8 & 20.2 & 5162536 & 92.1 \\
\hline
\end{tabular}


Notes: a: This column gives the number of secondary school students per children of 14-17 years of age which is considered to be the secondary school age.

b: The number of secondary schools, students and teacher provided in this table include all kinds of general and vocational and technical high schools.

Source: The number of secondary school teachers and students are from Ministry of National Education (2013).

The population of age 14-17 is obtained from TURKSTAT (2013). 
Appendix Table: Selected Results of a Survey on Supplementary Education Centers (SEC) Conducted by TED, Turkey, 2005.

\begin{tabular}{|c|c|c|c|}
\hline & $\begin{array}{c}\text { High School } \\
\text { Senior Students } \\
\%\end{array}$ & $\begin{array}{l}\text { High School } \\
\text { Graduates }{ }^{\mathrm{a}} \%\end{array}$ & $\begin{array}{l}\text { University } \\
\text { Students }{ }^{\mathrm{b}} \%\end{array}$ \\
\hline Number Interviewed & 1078 & 1073 & 1064 \\
\hline \multicolumn{4}{|c|}{$\begin{array}{l}\text { 1. Is There Anything in Your Life Now More Important Than The University Entrance } \\
\text { Examination? }\end{array}$} \\
\hline Yes & 24 & 21 & - \\
\hline No & 60 & 66 & - \\
\hline \multicolumn{4}{|c|}{ 2. Are You Currently Attending SECs? } \\
\hline Yes & 70 & 68 & 83 \\
\hline No & 25 & 23 & 16 \\
\hline \multicolumn{4}{|c|}{ 3. Where is the Quality of Education Better in? } \\
\hline SEC & 44 & 65 & 34 \\
\hline Schools & 6 & 3 & 10 \\
\hline $\begin{array}{l}\text { SEC Teach Only Examination } \\
\text { Techniques }\end{array}$ & 17 & 20 & 32 \\
\hline \multicolumn{4}{|c|}{ 4. Possibility of Success at University Entrance without SEC? } \\
\hline Possible & 44 & 35 & 49 \\
\hline Difficult or Not Possible & 58 & 64 & 50 \\
\hline \multicolumn{4}{|c|}{ 5. The Most Important Reason for Attending SECs } \\
\hline $\begin{array}{l}\text { School Education is not } \\
\text { Adequate for Success in } \\
\text { University Entrance Examination }\end{array}$ & 58 & 77 & 57 \\
\hline \multicolumn{4}{|c|}{$\begin{array}{l}\text { 6. How Much Do You Believe that SEC will Contribute to Your Success at the University } \\
\text { Entrance Examination? }\end{array}$} \\
\hline Will Contribute a Lot & 52 & 67 & - \\
\hline Will not Contribute Much & 16 & 14 & - \\
\hline Will not Contribute & 3 & 3 & - \\
\hline \multicolumn{4}{|c|}{ 7. Where is the Quality of Counseling and Guidance Services Better at? } \\
\hline SEC & 38 & 52 & 35 \\
\hline Schools & 8 & 4 & 12 \\
\hline Both Places & 36 & 30 & 27 \\
\hline \multicolumn{4}{|c|}{$\begin{array}{l}\text { 8. How Does Preparing for the University Examination Affect your Second Semester } \\
\text { School Attendance? }\end{array}$} \\
\hline Will receive Medical Report & 55 & 49 & 44 \\
\hline $\begin{array}{l}\text { Will Use Allowed } \\
\text { Non-Attendance Days }\end{array}$ & 24 & 21 & 25 \\
\hline Will Continue School & 19 & 29 & 29 \\
\hline \multicolumn{4}{|l|}{ 9. Do You Like Schools or SEC? } \\
\hline SEC & 23 & 29 & - \\
\hline Schools & 20 & 22 & - \\
\hline Both Places & 30 & 37 & - \\
\hline \multicolumn{4}{|c|}{ 10. Are You Satisfied with the SEC You are Attending? } \\
\hline Yes & 54 & 67 & 43 \\
\hline Partly & 18 & 28 & 36 \\
\hline I regret & 5 & 4 & 11 \\
\hline \multicolumn{4}{|c|}{ 11. How Many Hours of Education per Week Do You Get at SECs? } \\
\hline $0-10$ Hours & 13 & 6 & 16 \\
\hline
\end{tabular}




\begin{tabular}{|c|c|c|c|}
\hline $10-15$ Hours & 36 & 6.9 & 29 \\
\hline 15- 20 Hours & 15 & 51 & 28 \\
\hline $20+$ Hours & 8 & 33 & 15 \\
\hline \multicolumn{4}{|c|}{ 12. What is The Attitude of your School Teacher and Administrators Towards SECs? } \\
\hline Do not Think Necessary & 12 & 17 & 10 \\
\hline Absolutely Want Me to Go & 47 & 43 & 50 \\
\hline No Comment & 40 & 40 & 39 \\
\hline \multicolumn{4}{|c|}{$\begin{array}{l}\text { 13. Is the Quality of High School Important Determinant of Success at University Entrance } \\
\text { Examination? }\end{array}$} \\
\hline Yes & 67 & 67 & 67 \\
\hline Partly & 26 & 26 & 26 \\
\hline No & 7 & 6 & 7 \\
\hline \multicolumn{4}{|c|}{ 14. How Much will you Pay to the SECs this year? } \\
\hline Less than 500 YTL & 5 & 2 & 9 \\
\hline $500-1000 \mathrm{YTL}$ & 12 & 17 & 28 \\
\hline 1000-2000 YTL & 38 & 60 & 34 \\
\hline 2000-3000 YTL & 10 & 14 & 8 \\
\hline $3000-4000 \mathrm{YTL}$ & 3 & 1 & 4 \\
\hline Over 4000 YTL & 5 & 2 & 3 \\
\hline No Reply & 28 & 4 & 15 \\
\hline
\end{tabular}

Notes: a: High school graduate and attending Supplementary education Centers.

b: University Preparatory School or first year university students. The questions addressed to this group refer to their experiences prior to their success at the university entrance examination.

Source: Turkish Educational Association (TED) (2005). Various Tables.

This table is prepared from the information provided in TED (2005). En extended version of this table which include responses of the parents, the teachers and of the school administrators can be found in Tansel and Bircan (2007). 


\section{References}

Akgün, M. (2005). Özel dersanelere ayrılan ekonomik kaynakların incelenmesi (An investigation of the economic resources devoted to supplementary education centers). Paper presented at the Educational Sciences Congress, 28-30 September, 2005, Pamukkale University, Denizli, Turkey.

Altınyelken, H. K. (2013) The Demand for Private Tutoring in Turkey. In Bray, M., Mazawi, A. E. \& Sultana, R. G. (2013). Private Tutoring Across the Mediterranean, Rotterdam, The Netherlands: Sense Publishers. EuroMediterranean Centre for Educational Research.

Assaad, R. \& El-Badawy, A. (2004). Private and group tutoring in Egypt: Where is the gender inequality? Paper presented at the workshop on Gender Work and Family in the Middle East and North Africa, University of Minnesota.

Baştürk, S. \& Doğan, S. (2010) Lise öğretmenlerinin özel dersaneler hakkındaki görüşlerinin incelenmesi ( Investigating high school teachers' views on cram schools) Uluslarasi Insan Bilimleri Dergisi (International Journal of Human Sciences), 7(2), 135-157.

Berberoğlu, G. \& Kalender, I. (2005) Öğrenci başarısının yıllara, okul türlerine, bölgelere göre incelenmesi: ÖSS ve PISA analizi (Analysis of student achievement by year, school type and regions: ÖSS and PISA analysis), Eğitim Bilimleri ve Uygulama (Educational Sciences and Practice), 4(7), 2135 .

Berberoğlu, G. \& Tansel, A. (2013) Private tutoring and academic performance: evidence from Turkey, International Review of Education, forthcoming.

Bray, M. (1999). The shadow education system: private tutoring and its implications for planners. Fundamentals of educational planning No. 61. Paris: UNESCO International Institute for Educational Planning (IIEP).

Bray, M. (2003). Adverse effects of private supplementary tutoring: Dimensions, implications, and government responses. Paris: UNESCO International Institute for Educational Planning (IIEP).

Bray, M. (2006). Private supplementary tutoring: comparative perspectives on patterns and implications, Compare: A Journal of Comparative Education, 36 (4), $515-530$.

Bray, M. (2009). Confronting the shadow education system: what government policies for what private tutoring. Paris: UNESCO International Institute for Educational Planning (IIEP). 
Bray, M. (2010). Researching shadow education: Methodological challenges and directions, Asia Pacific Education Review, 11 (1), 3-13.

Bray, M. (2011). The challenge of shadow education: Private tutoring and its implications for policy makers in the European Union. Brussels, Belgium: European Commission.

Bray, M. \& Kwok, P. (2003). Demand for private supplementary tutoring: Conceptual considerations, and socio-economic patterns in Hong Kong, Economics of Education Review, 22 (6), 611-620.

Bray, M. \& Lykins, C. (2012) Shadow education: Private supplementary tutoring and its implications for policy makers in Asia. Hong Kong: Comparative Education Research Center, The University of Hong Kong.

Bray, M. \& Suso, E. (2008). The challenges of private supplementary tutoring: Global patterns and their implications for Africa. Maputo, Mozambique: Presented at the Biennale of the Association for the Development of Education in Africa.

Bray, M., Mazawi, A. E. \& Sultana, R. G. (2013). Private tutoring across the Mediterranean, Rotterdam, The Netherlands: Sense Publishers. EuroMediterranean Centre for Educational Research.

Burch, P. (2009). Hidden markets: The new education privatization, London, UK: Routledge publishers.

Dang, H.A. \& Rogers, H. (2008). The growing phenomenon of private tutoring: Does it deepen human capital, widen inequalities, or waste resources? The World Bank Research Observer, 23(2) 161-200.

Di Paolo, A. \& Tansel, A. (2013). Returns to foreign language skills in a developing country: The case of Turkey. Department of Economics, Barcelona University, Barcelona, Spain and Middle East Technical University, Ankara Turkey.

Dinçer, M. A. \& Uysal G. (2010). Determinats of student achievement in Turkey. Istanbul, Turkey: Bahçeşehir University Center for Economic and Social Research (BETAM) Working Paper.

Ekici, G. (2005). Öğrencilerin ÖSYM sınavına karsı tutumlarının bir çok değişkenle incelenmesi. (An investigation of the attitudes of students' toward the student selection examination through a number of variables). Educational Administration, 28, 82-90.

Gök, F. (2006). Üniversiteye girişte umut pazarı: Özel dershaneler (Hope market in the entrance to universities: Supplementary education centers), Eğitim, Bilim, Society, 8: 102-109. 
Gök, F. (2010) Marketing hope: Private institutions preparing students for the university entrance examination in Turkey, In S. Karin Amos (ed.) International Educational Governance, International Perspectives on Education and Society, 12, 123-134.

Güven-Der (Güven Dershane Sahipleri Derneği) (Association of the Owners of Güven Supplementary education Centers), (July, 2013). Retrieved from http://www.guvender.org.tr/

Güvercin, G. (2005) Özel dersanelerde ve MEB'e bağlı okullarda öğretmenlik yapan öğretmenlerin, öğretmenlik mesleği ile ilgili tutumlarının karşılaştırılması, Özel dersanelerde öğrenim gören lise-3 öğrencilerinin dersaneye ilişkin görüşleri (A comparison of the views of supplementary education center teachers and Ministry of National Education teachers on teaching profession, Views of high school senior students who are attending supplementary education centers on private tutoring centers) Paper presented at the Educational Sciences Congress, 28-30 September, 2005, Pamukkale University, Denizli, Turkey.

Haber-Türk Newspaper (2012). Üniversite sınavları kaldırılacak ve dersaneler kapanacak (The university entrance exam is going to be abolished and private tutoring centers will be closed down) 25 March, 2012.

Heyneman, S. P. (2011). Private tutoring and social cohesion. Peabody Journal of Education , 86, 183-188.

Higher Education Board of Turkey (Yüksek Öğretim Kurumu) (YÖK). (July, 2013). Retrieved from http://www.yok.gov.tr/

Higher Education Board of Turkey (Yüksek Öğretim Kurumu) (YÖK). (2007). Türkiye'nin Yüksek Öğretim Stratejisi (Higher Education Strategy for Turkey), Yüksek Öğretim Kurumu, Ankara.

Hürriyet Newspaper (2012) YGS ve dersaneler kalkıyor (University entrance examination and private tutoring centers will be eliminated), Hüriyet Newspaper, 25 March, 2012.

Independent Educators Union (Bağımsız Eğitimciler sendikası) (2007) Çocuklarımızı sahtekarlığa alıştırıyoruz. (We allow our children to cheat). Press Release, May 24, 2007 Ankara, Turkey.

Ireson, J. (2004). Private Tutoring: How Prevalent and Effective is it? London Review of Education, 2(2), 109-122.

Kim, H. (2008). After-school programs in Korea: A policy for reducing the heavier reliance on private education. Seoul, Korea: Korean Education Development Institute. 
Köprülü, F. (2012). Ekonomist dergisinin sorularına iliskin açıklamalarımız (Explanations for the questions by the Economist journal).Mimeo provided by ÖZ-DE-BİR.

Lee, C. J:, H. J. Park and H. Lee (2009) Shadow education system. In G. Sykes, B. Schneider and D: N: Plank (Eds.) Handbook of education policy research. New York, USA: Routledge publishers for the American Educational Research Association.

Milliyet Newspaper, (2012). Dersanelerin kapanacağı ve sınavların kalkacağı söyleniyor (They say supplementary tutoring centers will be closed down and the examinations will be abolished). 27 March, 2012

Ministry of National Education. (2006, 2007, 2012, 2013). National education statistics, formal education, 2012-2013, Ankara, Turkey: The Ministry of NationalEducation, the Presidency of Strategy Development.

Morgil, I. Y1lmaz, A. Seçken, N. \& Erökten, S. 2000. An assessment of the contribution of trial OSS examinations organized by private tutoring centers and ÖZ-DE-BİR on student success at university entrance examination Hacettepe Üniversitesi Ĕ̈itim Fakültesi Dergisi (Journal of the Hacettepe University School of Education), 19, 96-103.

Morgil, I., A. Yılmaz \& Geban, O. (2001) Özel dersanelerin üniversiteye girişte ögrenci başarısına etkileri (The effect of private tutoring centers on the success of students in the university entrance examinations), Hacettepe Üniversitesi Ĕ̈itim Fakültesi Dergisi ( Journal of the Hacettepe University School of Education), Vol. 21, pp. 89-96.

Mori, I. \& Baker, D. (2010) The origin of universal shadow education: What the supplemental education phenomenon tells us about the postmodern institutions of education. Asia Pacific Education Review, 11(1), 36-48.

Nartgün, Ş. S., Altındağ, Ü. \& Özen, R. (2012). Dersanelerin Öğrencilerin sosyal ve ekonomik yaşamları üzerine etkisi (The impact of Private tutoring on social and economic lives of students), Journal of Educational and Instructional Studies in the World, 2(1), 54-61.

ÖZ-DE-BİR (Özel Dershaneler Birliği) (Association of supplementary education centers). (July, 2013). Retrieved from http://www.ozdebir.org.tr/

Okur, M. \& Dikici, R. (2004). A comparative analysis of supplementary education centers and public schools. Kastomonu Ĕ̈itim Dergisi ( Kastomonu Journal of Education), 12 (2), 417-426. 
Safarzynska, K. (2013). Socio-economic determinants of demand for private tutoring. European Sociological Review, 29(2): 139-154.

Silova, I. (2009). Private supplementary tutoring in central Asia: New opportunities and burdens, Paris: UNESCO International Institute for Educational Planning (IIEP).

Silova, I. (2010). Private tutoring in Eastern Europe and Central Asia: Policy choices and implications, Compare: A Journal of Comparative and International Education, 40(3), 327-344.

Silova, I., Budiene, V. \& Bray, M. (eds.) (2006) Education in the hidden market place: Monitoring of supplementary education. New York, USA: Open Society Institute.

Stevenson, D. L. \& Baker, D. P. (1992). Shadow education and allocation in formal schooling: Transition to university in Japan, American Journal of Sociology, 97 (6), 1639-1657.

Student Selection and Placement Center (Öğrenci Seçme ve Yerleştirme Merkezi) (ÖSYM), (July, 2013) Retrieved from http://www.osym.gov.tr

Tansel, A. (1994). Wage employment, earnings and returns to schooling for men and women in Turkey. Economics of Education Review, 13 (4), 305-320.

Tansel, A. (2001). Self-employment, wage employment and returns to schooling by gender in Turkey. In Labor and Human Capital in the Middle East: Studies of markets and household behavior (pp. 337-367), Djavad Salehi-Isfahani (Ed.). Reading, USA: Ithaca Press. Another version appeared as "Self Employment, Wage Employment and Returns to Education for Urban Men and Women in Turkey" in Education and the Labor Market in Turkey, Tuncer Bulutay (Ed.). Ankara, Turkey: SIS Publication, pp.175-208 .

Tansel, A. (2002a). Determinants of schooling attainment for boys and girls in Turkey: Individual, household and community factors. Economics of Education Review, 21, 455-470.

Tansel, A. (2002b). "General versus vocational high schools and labor market outcomes in Turkey", in Human Capital: Population Economics in the Middle East, İsmail Sirageldin (Ed.), Cairo, Egypt: Economic Research Forum and American University of Cairo Press.

Tansel, A. (2005). Public-private employment choice, wage differentials and gender in Turkey. Economic Development and Cultural Change, 53 (1), 453-477. 
Tansel, A. (2010) "Changing returns to education for men and women in a developing country: Turkey, 1994-2005," paper presented at the ESPE Conference, London, UK and at the MEEA conference, March 2009 in Nice, France.

Tansel, A. (2013) Private tutoring and equitable opportunities in Turkey: Challenges and policy implications, Mediterranean Journal of Educational Studies, 2013, forthcoming. Also published in Bray, M., A. E. Mazawi and R .G. Sultana (Eds.) (2013) Private Tutoring Across the Mediterranean, Rotterdam, The Netherlands: Sense Publishers, (177-186).

Tansel A. \& Bircan, F. (2005). Effect of supplementary education on university entrance examination performance in Turkey, Economic Research Forum WP No. 0407, Cairo, Egypt and IZA Discussion Paper No. 1609, Bonn, Germany.

Tansel, A. \& Bircan, F. (2006). Demand for education in Turkey: a Tobit analysis of supplementary education expenditures, Economics of Education Review, 25 (4), 303-313.

Tansel, A. \& Bircan, F. (2007) Supplementary education in Turkey: recent evidence on its various aspects, Paper presented at the UNESCO, IIEP Policy Forum on Confronting the Shadow Education System, Paris, 5-6 July 2007 and IZA Discussion Paper no: 3471, May 2008.

Tansel, A. \& Taşçı, H. M. (2010). Hazard analysis of unemployment duration by gender in a developing country: The case of Turkey. Labour: Review of Labor Economics and Industrial Relations, 2010, 24(4): 501-530.

TÖDER (Tüm Özel Öğretim Kurumları Derneği) (Association of All Private Educational Establishments). (July, 2013). Retrieved from http://www.toder.org/

Trade Union of Educators (Eğitim-Sen) (Eğitimciler Sendikası) (July, 2013). Retrieved from http://www.egitimsen.org.tr/

Turkish Educational Association (Türk Eğitim Derneği) (TED). (2005). Türkiye'de üniversiteye giriş sistemi araştırması ve çözüm önerileri (Study on the university placement system in Turkey and suggestions for solution), Ankara, Turkey:Türk Eğitim Derneği.

Turkish Satistical Institute (TURKSTAT) (2013) Retrieved from http://www.tuik.org.tr/

World Bank (2011) Improving the quality and equity of basic education in Turkey: 
Challenges and options, Washington DC, USA: The World Bank Human Development Department, Europe and Central Asia Region. Report No: 54131-TR.

Zhang, Y. (2013). Does private tutoring improve students' National College Entrance Exam performance?-A case study from Jinan, China. Economics of Education Review, 32, 1-28. 